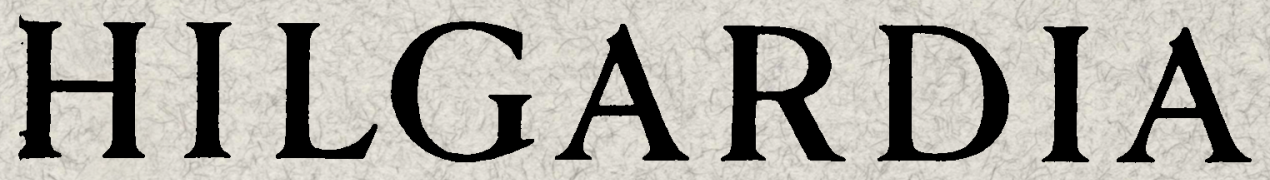

A Journal of Agricultural Science Published by the California Agricultural Experiment Station

$\begin{array}{lll}\text { VOLUME } 30 & \text { JUNE, } 1960 & \text { NUMBER } 1\end{array}$

\title{
Supplement To \\ AN ANNOTATED LIST AND \\ BIBLIOGRAPHY OF INSECTS REPORTED TO HAVE VIRUS DISEASES
}

MAURO E. MARTIGNONI

and

ROBERT L. LANGSTON

UNIVERSITY OF CALIFORNIA · BERKELEY, CALIFORNIA 


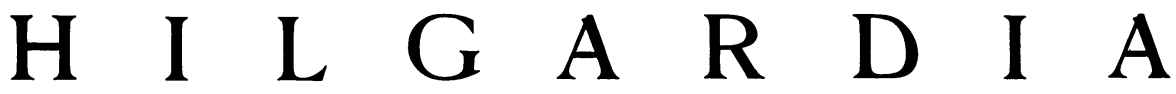

A Journal of Agricultural Science Published by

the California Agricultural Experiment Station

\section{Supplement to}

\section{AN ANNOTATED LIST AND BIBLIOGRAPHY OF INSECTS REPORTED TO HAVE VIRUS DISEASES ${ }^{1}$}

\section{MAURO E. MARTIGNONI ${ }^{2}$ and ROBERT L. LANGSTON ${ }^{3}$}

IN 1957 Hughes (166) laid the basis for the "Annotated List and Bibliography" by cataloguing a series of 259 papers dealing with virus infections of insects. While Hughes' list contains most of the important papers published on insect viruses and virus diseases, it does not include many reports which, even if not dealing primarily with virology or pathology, nonetheless contain valuable information for the insect pathologist. This first supplement adds 473 new references to the 259 already published in Hughes' list. Almost all these papers have been seen in the original or, in a few cases, in photostatic copy of the original (as we are quite adverse to the not uncommon practice of quoting from quotations, thus perpetuating errors). Where the linguistic knowledge of the authors was lacking, translators were consulted; in some cases complete translations were available with the original publication.

The present supplement, as in the list by Hughes, includes only a small proportion of the many papers in Japanese or Russian: those included were available in translation or contained a summary complete enough to derive sufficient information on the type of disease concerned. It is gratifying to know that a similar bibliographical survey is being completed at present in the U.S.S.R. (S. Gershenson, personal communication, 1958).

Titles of Japanese and Russian papers appear in translation only, the translation being that given in the summary of the original publication. Papers in English, French, German, and Italian are entered with their original titles and without translations. Translations and original titles appear for papers in Czech, Polish, and Croatian.

As in Hughes' list, an attempt was made to distinguish between nuclear polyhedrosis and cytoplasmic polyhedrosis whenever the information available permitted such a distinction. Those cases in which a polyhedrosis was involved, but without evidence to indicate the type of polyhedrosis, were recorded simply as "polyhedrosis."

\footnotetext{
${ }^{1}$ Contribution from the Laboratory of Insect Pathology, Department of Biological Control, University of California, Berkeley. Originally submitted for publication July 27, 1959.

${ }^{2}$ Lecturer in Insect Pathology and Assistant Insect Pathologist in the Experiment Station, Berkeley.

${ }^{3}$ Laboratory Technician in the Experiment Station, Berkeley.
} 
The sources for scientific and common names are the same as in Hughes' list. The only addition is the work "The North American sawflies of the genera Acantholyda, Cephalcia, and Neurotoma (Hymenoptera, Pamphiliidae)" by W. W. Middlekauff (Univ. Calif. Publ. Ent. 14:51-173; 1957), on which basis the generic name Cephalcia was adopted in place of Cephaleia.

The families are arranged alphabetically within the orders. Subgeneric names, where necessary, are in parentheses, after the generic name. In addition to the host list, a general list of references is included in this supplement. Abbreviations of periodicals are those of the "World List of Scientific Periodicals Published in the Years 1900-1950" edited by W. A. Smith, F. L. Kent, and G. B. Stratton (3d ed., Butterworths Scientific Publications, London, xvii-1058 pp.; 1952).

\section{ACKNOWLEDGMENTS}

We are very grateful to Dr. E. A. Steinhaus for having permitted the use of his large reprint collection; to Dr. F. Baldassini and Mr. J. E. Milstead for their generous help in phases of this work ; and to the library of the University of California, an invaluable instrument of research.

\section{HOST LIST}

\section{ARACHNIDA}

ACARINA

"Seta-suppressor substance" (72)

TETRANYCHIDAE

Tetranychus cinnabarinus (Bdv.)

\section{INSECTA LEPIDOPTERA}

AGROTIDAE

(See PHALAENIDAE)

ANTHELIDAE

Pterolocera amplicornis Wlk.

Nuclear polyhedrosis $(93,327)$

ANTHROCERIDAE

(See ZYGAENIDAE)

ARCTIIDAE

Apantesis virgo (L.)

Polyhedrosis (137)

Arctia caja (L.), great tiger moth

Nuclear polyhedrosis $(324,336)$

Cytoplasmic polyhedrosis $(124,329,336,383)$

Polyhedrosis (412)

Arctia villica (L.), cream-spot tiger moth

Cytoplasmic polyhedrosis $(47,48,124,327,336)$ 
Ardices glatignyi (Le Guill.), woolly bear

Nuclear polyhedrosis (364)

Cycnia mendica (Clerck), muslin moth

Nuclear polyhedrosis (336)

Diacrisia purpurata (L.)

Cytoplasmic polyhedrosis (336)

Estigmene acrea (Drury), salt-marsh caterpillar

Granulosis $(47,74)$

Euplagia quadripunctaria (Poda), Jersey tiger moth

Cytoplasmic polyhedrosis (336)

Hyphantria cunea (Drury), fall webworm

Nuclear polyhedrosis $(212,234,235,350)$

Cytoplasmic polyhedrosis (389)

Polyhedrosis $(194,231)$

Granulosis $(196,314)$

Hypocrita jacobeae (L.), cinnabar moth

Nuclear polyhedrosis (336)

Panaxia dominula (L.), scarlet tiger moth

Nuclear polyhedrosis $(323,327,336,411,414)$

Phragmatobia fuliginosa (L.), ruby tiger moth

Cytoplasmic polyhedrosis (336)

\section{BOMBYCIDAE}

Bombyx mori (L.), silkworm

Nuclear polyhedrosis $(3,4,5,6,7,8,9,10,11,12,13,14,15,16,17,18$, $19,21,30,32,33,34,35,38,43,45,47,48,50,51,52,57,70,71,74,77$, $80,83,90,91,94,95,99,100,104,105,107,108,111,112,113,116,133$, $134,135,137,139,144,145,146,147,155,162,163,165,169,171,173$, $175,176,177,179,185,187,197,198,199,202,203,208,213,215,217$, $219,220,222,229,232,233,236,237,242,243,244,245,246,247,248$, $249,253,256,263,264,266,267,268,271,273,276,278,280,283,284$, $285,286,287,288,293,296,297,302,303,305,306,308,316,317,324$, $326,327,338,339,354,355,356,360,361,362,363,368,369,370,371$, $372,373,374,375,376,377,378,379,380,381,382,383,384,387,393$, $396,398,401,402,403,408,410,414,416,417,418,419,420,421,422$, $423,424,425,426,427,428,429,430,431,432,433,434,435,436,437$, $438,439,440,441,442,443,444,445,446,447,448,449,450,451,452$, $453,454,455,456,457,458,459,460,461,462,463,464,465,466,467$, $468,469,470,471,472,473$ ) [Papers 424 and 473 refer to hybrids of Theophila mandarina and Bombyx mori]

Cytoplasmic polyhedrosis $(21,32,33,34,35,36,37,171,172,173,327$, 336 )

A poorly defined group of diseases, including those known as flacherie and gattine, believed by Paillot to result from infection by a virus and a bacterium $(100,242,244,269,270,271,272,274,275,276,277,278$, $279,280,282,376$ ) 
Theophila mandarina Moore, mulberry wild silkworm

Nuclear polyhedrosis $(32,424,462,473)$ [Papers 424 and 473 refer to hybrids of Theophila mandarina and Bombyx mori]

Cytoplasmic polyhedrosis (32)

\section{DIOPTIDAE}

Phryganidia californica Pack., California oakworm

Nuclear polyhedrosis $(47,74,137,159,170,341)$

\section{DREPANIDAE}

Drepana lacertinaria (L.)

Cytoplasmic polyhedrosis (329)

\section{GALLERIIDAE}

Galleria mellonella (L.), greater wax moth

Nuclear polyhedrosis (383)

"Galleria-adapted silkworm jaundice virus" (21)

\section{GELECHIIDAE}

Recurvaria milleri Busck, Lodgepole needle miner

Granulosis (347)

\section{GEOMETRIDAE}

Abraxas grossulariata (L.), currant moth

Nuclear polyhedrosis $(323,324,327,414)$

Cytoplasmic polyhedrosis (327)

Alsophila pometaria (Harr.), fall cankerworm

Cytoplasmic polyhedrosis (255)

Bupalus piniarius (L.)

Cytoplasmic polyhedrosis $(325,328)$

Polyhedrosis $(109,181)$

Unidentified particles in blood resembling virus inclusion bodies (327)

Crocallis elinguaria (L.)

Cytoplasmic polyhedrosis (336)

Ennomos quercinaria (Hfn.)

Nuclear polyhedrosis (168)

Eulype hastata (L.), spear-marked black moth

Granulosis (343)

Hibernia defoliaria (L.)

Nuclear polyhedrosis $(124,205,207)$

Lambdina fiscellaria fiscellaria (Guen.), hemlock looper

Polyhedrosis (301)

Lambdina fiscellaria lugubrosa (Hulst), western hemlock looper

Nuclear polyhedrosis $(291,310)$

Operophtera brumata (L.), winter moth

Nuclear polyhedrosis (330)

Cytoplasmic polyhedrosis (255, 325, 328, 330)

Oporinia autumnata (Borkh.), larch looper

Nuclear polyhedrosis (124) 
Ourapteryx sambucaria (L.), swallow tailed moth

Cytoplasmic polyhedrosis (336)

- Sabulodes caberata Guen., omnivorous looper

Granulosis (47, 327)

\section{LASIOCAMPIDAE}

Dendrolimus pini $\mathrm{L}$.

Polyhedrosis (135)

Malacosoma americanum (F.), eastern tent caterpillar

Nuclear polyhedrosis $(86,136,215,402,408)$

Polyhedrosis (137)

Malacosoma californicum (Pack.), California tent caterpillar

Nuclear polyhedrosis $(86,218)$

Malacosoma constrictum (Stretch)

Nuclear polyhedrosis $(86,218)$

Malacosoma disstria $\mathrm{Hbn}$., forest tent caterpillar

Nuclear polyhedrosis $(51,80,86,215,291,340,365,402)$

Polyhedrosis $(137,320)$

Malacosoma fragile (Stretch), Great Basin tent caterpillar

Nuclear polyhedrosis $(86,340)$

Malacosoma neustria (L.)

Nuclear polyhedrosis $(59,124,195)$

Polyhedrosis $(135,152,161,193,194)$

Malacosoma pluviale (Dyar), western tent caterpillar

Nuclear polyhedrosis (309)

\section{LIMACODIDAE}

Natada nararia (Moore), nettle grub of tea

Granulosis (167, 325, 326, 327, 328)

\section{LYCAENIDAE}

Lycaena phlaeas (L.), small copper butterfly

Cytoplasmic polyhedrosis (336)

\section{LYMANTRIIDAE}

Dasychira pudibunda (L.)

Cytoplasmic polyhedrosis $(124,206,208,214,317)$

Polyhedrosis (110)

Euproctis chrysorrhoea (L.), brown-tail moth

Nuclear polyhedrosis $(124,205)$

Polyhedrosis $(114,151,193,194)$

Euproctis flava (Bremer)

Nuclear polyhedrosis (20)

Euproctis pseudoconspersa (Strand)

Nuclear polyhedrosis (20)

Hemerocampa leucostigma (J. E. Smith), white-marked tussock moth Nuclear polyhedrosis $(142,143)$

Polyhedrosis (137) 
Hemerocampa pseudotsugata McD., Douglas-fir tussock moth

Polyhedrosis (291, 311)

Ivela auripes (Butler), yellow-legged tussock moth

Nuclear polyhedrosis (32)

Lymantria monacha (L.), nun moth

Nuclear polyhedrosis $(47,57,74,76,77,103,124,137,160,182,184,185$, $186,189,192,242,263,280,303,304,306,312,316,327,336,414)$

Cytoplasmic polyhedrosis (164)

Polyhedrosis $(45,106,107,108,114,132,138,141,161,191,257,292,295$, $298,307,366,367,394,395)$

Virus disease, not further identified (160)

Porthetria dispar (L.), gypsy moth

Nuclear polyhedrosis $(47,48,51,57,74,77,124,136,137,139,183,185$, $215,229,242,250,263,280,306,316,317,322,325,327,336,365,378$, $383,390,391,397,401,402,408,414)$

Cytoplasmic polyhedrosis $(336,392)$

Polyhedrosis $(22,44,45,106,107,108,114,135,138,187,193,194,195$, 196, 298, 299, 313, 338)

Stilpnotia salicis (L.) satin moth

Nuclear polyhedrosis $(124,401)$

NOCTUIDAE

(See PHALAENIDAE)

NOTODONTIDAE

Cerura hermelina (Goeze)

Nuclear polyhedrosis (276)

Cerura vinula (L.), puss moth

Cytoplasmic polyhedrosis (336)

Phalera bucephala (L.), buff tip moth

Nuclear polyhedrosis (336)

Cytoplasmic polyhedrosis $(329,336)$

\section{NYMPHALIDAE}

Aglais urticae (L.), small tortoiseshell butterfly

Nuclear polyhedrosis $(74,336)$

Cytoplasmic polyhedrosis (325)

Polyhedrosis (135)

Junonia coenia Hbn., buckeye

Nuclear polyhedrosis (339)

Granulosis $(47,74,339,341)$

Nymphalis io (L.), peacock butterfly

Nuclear polyhedrosis (336)

Polyhedrosis (135)

Vanessa atalanta (L.), red-admiral

Polyhedrosis (135)

Vanessa cardui (L.), painted lady butterfly

Nuclear polyhedrosis $(41,256,325,328,330,336)$ 
Cytoplasmic polyhedrosis $(41,256,325,328,330,336)$

Polyhedrosis $(135,328)$

OLETHREUTIDAE

Eucosma griseana (Hbn.), gray larch tortrix, larch bud moth

Polyhedrosis; viral nature of polyhedra not yet established $(174,176$, $179,180,203)$

Granulosis $(42,68,73,124,180,239,241)$

\section{PAPILIONIDAE}

Papilio machaon L.

Cytoplasmic polyhedrosis (329)

\section{PHALAENIDAE}

Agrotis segetum (Schiff.), turnipmoth or cutworm

Nuclear polyhedrosis $(74,281)$

Cytoplasmic polyhedrosis (330)

Granulosis (74)

Diataraxia oleracea (L.), tomato moth

Cytoplasmic polyhedrosis (330)

Euxoa ochrogaster (Guen.), red-backed cutworm

Granulosis (343)

Heliothis virescens (F.), tobacco budworm

Nuclear polyhedrosis (84)

Heliothis zea (Boddie), corn earworm, bollworm, tomato fruitworm

Nuclear polyhedrosis $(56,334)$

Lampra fimbriata (von Schreber), broad-bordered yellow underwing Cytoplasmic polyhedrosis (336)

Melanchra persicariae (L.), dot moth

Granulosis (329, 330)

Panolis flammea Schiff., pine moth

Polyhedrosis (109)

Peridroma margaritosa (Haw.), variegated cutworm

Nuclear polyhedrosis (339)

Granulosis $(47,74,167,327,337,339,341)$

Phlogophora meticulosa (L.), angleshades moth

Nuclear polyhedrosis $(336,414)$

Cytoplasmic polyhedrosis (325, 326, 327, 336)

Plusiagamma (L.)

Nuclear polyhedrosis $(59,386)$

Prodenia"litosia" [This is probably Prodenia litura (F.)]

Polyhedrosis (108)

Prodenia litura (F.), cotton leafworm

Nuclear polyhedrosis $(2,54)$

Prodenia praefica Grote, western yellow-striped armyworm

Nuclear polyhedrosis $(1,2,47,74,229)$

Pseudaletia unipuncta (Haw.), armyworm

Nuclear polyhedrosis $(25,75,115,137,238)$

Noninclusion virus disease $(327,330)$ 
Spaelotis clandestina (Harr.), W-marked cutworm

Polyhedrosis (137)

Spodoptera mauritia (Bdv.), lawn armyworm

Nuclear polyhedrosis $(58,353)$

Trichoplusia ni (Hbn.), cabbage looper

Nuclear polyhedrosis $(137,157,230,318)$

Triphaena pronuba (L.), yellow underwing

Cytoplasmic polyhedrosis (330)

\section{PHALONIIDAE}

Clysiana ambiguella (Hbn.)

Polyhedrosis (108)

\section{PHYCITIDAE}

Ephestia cautella (Wlk.), almond moth

Nuclear polyhedrosis (414)

\section{PIERIDAE}

Aporia crataegi (L.), black-veined white butterfly

Nuclear polyhedrosis $(124,206,208,209,211,212,317)$

Polyhedrosis $(135,346)$

Colias philodice eurytheme $\mathrm{Bdv}$., alfalfa caterpillar

Nuclear polyhedrosis $(1,25,47,74,80,85,87,88,154,215,294,325,340$, $341,342,344,345,348,358,359,402,408,409$ )

Colias philodice philodice Latr., clouded sulphur butterfly

Polyhedrosis (137)

Pieris brassicae (L.), European cabbage butterfly

Granulosis $(60,74,148,212,242,276,280,330,340)$

Possible virus disease with formation of polymorphic inclusion bodies $(74,242,265,276,280,287)$

Pieris napi (L.), mustard white

Granulosis (330)

Pieris rapae (L.), imported cabbageworm

Polyhedrosis (137)

Granulosis $(68,327,330,340,351)$

Virus disease, not further identified (300)

\section{PSYCHIDAE}

Cryptothelea junodi (Heylaerts), wattle bagworm

Nuclear polyhedrosis $(258,259,260,261,262,321)$

\section{SATURNIIDAE}

Antheraea paphia mylitta (Drury)

Cytoplasmic polyhedrosis (331)

Antheraea pernyi Guér.-Men., Chinese oak silkworm

Polyhedrosis $(135,293)$

Antheraea polyphemus (Cram.), polyphemus moth

Nuclear polyhedrosis $(323,324,336)$

Hemileuca maia (Drury), buck moth

Polyhedrosis (137) 
Samia cynthia (Drury), Cynthia moth

Nuclear polyhedrosis $(325,336)$

Cytoplasmic polyhedrosis (336)

Polyhedrosis (293)

Samia ricini (Bdv.), Arrindy silkorm

Nuclear polyhedrosis $(32,188,336)$

Saturnia pyri (Schiff.)

Nuclear polyhedrosis (276)

\section{SATYRIDAE}

Dira megera (L.), wall butterfly

Cytoplasmic polyhedrosis (336)

Pararge aegeria (L.), speckled wood butterfly

Cytoplasmic polyhedrosis (336)

\section{SELIDOSEMIDAE}

(See GEOMETRIDAE)

\section{SPHINGIDAE}

Celerio euphorbiae (L.), spurge hawk moth

Polyhedrosis (412)

Laothoe populi (L.), poplar hawk moth

Nuclear polyhedrosis (336)

Cytoplasmic polyhedrosis $(317,415)$

Smerinthus ocellata atlanticus Austaut

Polyhedrosis (108)

Sphinx ligustri L., privet hawk moth

Nuclear polyhedrosis (336)

Cytoplasmic polyhedrosis $(331,336)$

\section{THAUMETOPOEIDAE}

Thaumetopoea pityocampa Schiff.

Nuclear polyhedrosis $(59,61,149,376,388)$

Cytoplasmic polyhedrosis $(61,317,385,415)$

\section{TINEIDAE}

Tinea pellionella (L.), casemaking clothes moth

Nuclear polyhedrosis $(325,336)$

Cytoplasmic polyhedrosis $(325,336)$

Tineola bisselliella (Hum.), webbing clothes moth

Nuclear polyhedrosis $(323,325,383)$

Cytoplasmic polyhedrosis $(323,325)$

Polyhedrosis $(27,403)$

\section{TORTRICIDAE}

(See also OLETHREUTIDAE and PHALONIIDAE)

Acleris variana (Fern.), black-headed budworm

Nuclear polyhedrosis (291)

Argyrotaenia velutinana (Wlk.), red-banded leaf roller

Granulosis $(47,140,315,319,327)$ 
Cacoecia murinana ( $\mathrm{Hbn}$.), fir shoot roller

Nuclear polyhedrosis $(82,216)$

Granulosis (47, 48, 74, 79, 82, 124, 215, 229, 306, 316, 327, 402, 407, 408)

Choristoneura fumiferana (Clem.), spruce budworm

Nuclear polyhedrosis $(47,48,62,80,215,229,252,291,402)$

Cytoplasmic polyhedrosis (254)

Granulosis $(48,68,81,215,229,252)$

\section{ZYGAENIDAE}

Harrisina brillians B. \& McD., western grape leaf skeletonizer

Granulosis $(88,156)$

SCARABAEIDAE

\section{COLEOPTERA}

Melolontha hippocastani L.

Virus disease, not further identified (160)

Melolontha melolontha $\mathrm{L}$.

Virus disease, not further identified (160)

\section{APIDAE}

\section{HYMENOPTERA}

Apis mellifera L., honey bee

"Paralysis," a noninclusion virus disease $(251,330)$

Sacbrood, a noninclusion virus disease $(74,131,137,242,330)$

Pathogenic drone brood, a possible virus disease of the queen bee, with inclusion bodies $(127,128,129,130)$

Diprion (Gilpinia) hercyniae (Hartig), European spruce sawfly

Nuclear polyhedrosis $(39,40,41,52,64,65,66,69,81,96,117,120,124$, $291,327,340,348,357$ )

Neodiprion lecontei (Fitch) red-headed pine sawfly

Nuclear polyhedrosis $(66,291)$

Neodiprion pratti banksianae Roh., jack-pine sawfly

Nuclear polyhedrosis $(66,67,291,340)$

Neodiprion pratti pratti (Dyar)

Polyhedrosis $(44,97)$

Neodiprion sertifer (Geoff.), European pine sawfly

Nuclear polyhedrosis $(25,39,41,44,63,64,66,81,97,98,117,118,119$, $120,121,123,124,125,126,200,201,204,208,210,291,294,325,327$, $340,348,357,402,408$ )

Polyhedrosis $(107,108,110)$

\section{PAMPHILIIDAE}

Acantholyda (Itycorsia) nemoralis C. G. Thomson

Virus disease, not further identified (160)

Cephalcia (Cephalcia) abietis L.

Polyhedrosis; viral nature of polyhedra not yet established (175, 176, 203, 207) 


\section{TENTHREDINIDAE}

Nematus olfaciens Benson, black currant sawfly

Nuclear polyhedrosis (325)

\section{DIPTERA}

\section{CHIRONOMIDAE}

(See TENDIPEDIDAE)

CULICIDAE

Anopheles subpictus Grassi

A possible virus disease with inclusion bodies (92)

\section{DROSOPHILIDAE}

Drosophila melanogaster Meig.

Virus " $\sigma$ " (78, 101, 102, 150, 221, 223, 224, 225, 226, 227, 228, 289, 290)

\section{TENDIPEDIDAE}

Chironomus tentans $\mathrm{F}$.

A possible virus disease with inclusion bodies $(158,399)$

\section{TIPULIDAE}

Tipula (Tipula) paludosa Meig., leatherjacket

Nuclear polyhedrosis $(31,325,326,327,328,329,330,335)$

Tipula iridescent virus $(31,190,317,325,327,328,329,330,331,332$, $333,335,405,406$ )

\section{SUBJECT LIST}

Included in this section are reviews on insect viruses as well as papers concerned primarily with the biological, biophysical, and biochemical properties of insect viruses as a group. A large number of these papers are listed also with certain hosts, if the information seems of interest for a particular virushost system. Since reviews on insect viruses $(e . g ., 53)$ usually mention a large number of hosts from the literature, without adding new information, they have not been listed in the host catalogue.

VIRUSES, INCLUDING THOSE OF INSECTS (Reviews)

24, 229, 306, 316, 317, 326, 328

INSECT VIRUSES ONLY (Reviews)

$46,51,53,137,178,242,276,280,292$

TAXONOMY AND NOMENCLATURE $23,47,74,400$

MORPHOLOGY AND DEVELOPMENT

$48,49,306,326,327,404,413$ 


\section{ETIOLOGY}

$52,324,339,341,383,421$

MICROBIAL CONTROL

$25,28,29,80,87,88,109,153,193,330,340,342,349,352$

METHODS AND TECHNIQUES

$26,55,76,203,212,216,217,239,240,371,375,381$

BIBLIOGRAPHIES

$53,89,122,166,242$ 


\section{BIBLIOGRAPHY}

1. AbUL-NASR, S.

1954. The formation of polyhedra in the gut epithelial cells of virus-infected insects. Bull. Soc. Fouad Ent. 38:383-95.

2. ABUL-NASR, S.

1956. Polyhedrosis-virus disease on cotton leaf-worm, Prodenia litura F. Bull. Soc. ent. Égypte $40: 321-32$.

3. ACQUA, C.

1918. Ricerche sulla malattia del giallume nel baco da seta. R.C. Ist. bacol. Portici $3: 243-56$.

4. ACQUA, C.

1936. Ricerche eseguite alla R. Stazione di Gelsibachicoltura di Ascoli Piceno. Ric. sci., Ser. 2, 1:54-55.

5. Aizawa, K.

1952. On the virus amount in the fractions of the polyhedral bodies of the silk-

6. Aizawa, K. worm jaundice in the isoelectric precipitation. Jap. J. appl. Zool. 17:56-60.

1952. Some immunological characters on the blood, jaundice-diseased blood and polyhedral bodies in Bombyx mori L. Sanshi-kenkyu 1:49-53.

7. Aizawa, K.

1952. Turbidity-time curve of the infected blood in the silkworm jaundice. Sanshikenkyu 2:78-80.

8. Aizawa, K.

1953. On the dissolving curve of the polyhedral bodies of the silkworm jaundice in $\mathrm{Na}_{2} \mathrm{CO}_{3}$ solution. Jap. J. appl. Zool. 17:145-54.

9. Aizawa, K.

1953. On the inactivation of the silkworm jaundice virus. Jap. J. appl. Zool. 17:18390.

10. Aizawa, K.

1953. Silkworm jaundice virus in the excrements of the infected larvae. Jap. J. appl.

11. Aizawa, K. Zool. 18:143-44.

1953. Some methods of keeping the virus activity of the silkworm jaundice. Sanshikenkyu 3:75-77.

12. Aizawa, $\mathrm{K}$.

1953. Multiplication mode of the silkworm jaundice virus. I. On the multiplication mode in connection with the latent period and LD 50 - time curve. Bull. seric. Exp. Sta. Japan 14:201-28.

13. Aizawa, $\mathrm{K}$.

1954. Dissolving curve and the virus activity of the polyhedral bodies of Bombyx mori L., obtained 37 years ago. Sanshi-kenkyu 8:52-54.

14. Aizawa, K.

1954. Immunological studies of the silkworm jaundice virus. (1) Neutralization and absorption test of the silkworm jaundice virus. Virus [Japan] 4:238-40.

15. Aizawa, K.

1954. Immunological studies of the silkworm jaundice virus. (2) Agglutination reaction of the polyhedral bodies. Virus [Japan] 4:241-44.

16. AizaWa, K.

1954. Immunological studies of the silkworm jaundice virus. (3) Experiments on

17. Aizawa, K. the defence of infection in the silkworm jaundice. Virus [Japan] 4:245-48.

1954. Neutralization of silkworm jaundice virus by human serum. Nature 174:748 49.

18. Aizawa, K.

1955. A preliminary note on the tetragonal polyhedra in the silkworm, Bombyx mori. Sanshi-kenkyu No. 14-4:11-13. 
19. Aizawa, K.

1955. Inactivation of the silkworm jaundice virus by the ultraviolet irradiation. J. seric. Sci. [Tokyo] 24:398-99.

20. Aizawa, K., S. Asahina, and H. Fukumi

1957. Demonstration of the polyhedral diseases of Euproctis flava and Euproctis pseudoconspersa (Lepidoptera, Lymantriidae). Japan. J. med. Sci. Biol. 10:61-64.

21. Aizawa, K., and S. Murai

1957. Electrophoresis of the blood of the silkworm, Bombyx mori on filter paper (2nd report). Biological Physies and Chemistry [Japan] 4(1/2):23-26.

22. Allen, H. W.

1916. Notes on the relation of insects to the spread of the wilt disease. J. econ Ent. $9: 233-35$.

23. ANDREweis, C. H., Chairman

1953 (1955). Report of the subcommittee on viruses. Act. $6^{\text {me }}$ Congr. int. Microbiol., Rome, 7 (Appendix) : 109-11.

24. ANDREWes, C. H.

1957. Factors in virus evolution. Advane. Virus Res. 4:1-24.

25. ANONYMOUS

1954. Diseases can destroy insects. Agric. Res., U. S. Dep. Agric. 2(12) :18.

26. ANONYMOUS

1955. Entomology Laboratory, biological control investigations, Belleville, Canada. Agric. Inst. Rev. 10 (6) :19-24.

27. ANONYMOUS

1956. Virus to control clothes moths? Pest Control 24(4):60.

28. ANONYMOUS

1956. Virus vs. insect. J. agric. Food Chem. 4:195-96.

29. ANONYMOUS

1957. They're mounting biological war on bugs. Chem. Week 78:80-82, 84, 86 .

30. AOKI, K., and Y. CHIGASAKI

1921. Immunisatorische Studien über die Polyederkörperchen bei Gelbsucht von Seidenraupen (Zelleinschluss). Zbl. Bakt., Abt. I, 86:481-85.

31. Armstrong, J. A., and Janet S. F. Niven

1957. Histochemical observations on cellular and virus nucleic acids. Nature 180: $1335-36$.

32. Aruga, $\mathrm{H}$.

1957. Polyhedral diseases in the silkworm, Bombyx mori L. Rev. Ver à Soie 9:37-41.

33. Aruga, H.

1957. Mechanism of resistance to virus diseases in the silkworm, Bombyx mori. II.

On the relation between the nuclear polyhedrosis and the cytoplasmic poly-

34. Aruga, H. hedrosis. J. seric. Sci. [Tokyo] $26: 279-83$.

1958. Mechanism of resistance to virus diseases in the silkworm, Bombyx mori. IV. On the relation between the polyhedral diseases and environmental factors.

35. Aruga, H. J. seric. Sci. [Tokyo] $27: 5-9$.

1958. Mechanism of resistance to virus diseases in the silkworm, Bombyx mori. V. On the induction of the polyhedral virus by nitrogen mustard. J. seric. Sci. [Tokyo] $27: 10-13$.

36. ARUGa, $\mathrm{H}$.

1958. Mechanism of resistance to virus diseases in the silkworm, Bombyx mori. VI. On the relation between the rearing season and the cytoplasmic polyhedrosis.

37. Aruga, H.

J. seric. Sci. [ Tokyo] $27: 14-17$.

1958. Cytoplasmic polyhedrosis in the silkworm, Bombyx mori L. Mimeo. 3 pp.

38. Aruga, H., H. Watanabe, T. Fukuhara, and Y. IWashita

1957. Mechanism of the virus resistance in the silkworm, Bombyx mori. I. On the formation of the polyhedral body in the nucleus of the silk-gland cell. J. seric. Sci. [Tokyo] $26: 1-8$. 
39. BAIRD, A. B.

1956 (1958). Biological control of insect and plant pests in Canada. Proc. 10th int. Congr. Ent., Montreal, 4 :483-85.

40. BALCH, R. E.

1945. The spruce sawfly disease. For. Insect Invest. [Ottawa] 1(2):1.

41. BALCH, R. E.

1958. Control of forest insects. Annu. Rev. Ent. 3:449-68.

42. BALTENSWEILER, W.

1958. Zur Kenntnis der Parasiten des grauen Lärchenwicklers (Zeiraphera griseana

Hübner) im Oberengadin. Mitt. schweiz. Anst. forstl. Versuchsw. 34:399-478.

43. Bassi, A.

1835. Del mal del segno ealcinaccio o moseardino malattia che affligge $i$ bachi da seta e sul modo di liberarne le bigattaje anche le più infestate. Tipografia Orcesi, Lodi. First part, xi-67 pp.; second part, xiv-60 pp. Facsimile edition: Istituto Geografico De Agostini, Novara, 1956.

44. BeAL, J. A.

1956 (1958). Status and trends in forest insect research. Proc. 10th int. Congr. Ent., Montreal, 4:323-30.

45. Bergold, G. H.

1942. Polyederfreie Insektenzuchten. Naturwissenschaften $30: 422-33$.

46. BERGOLD, G. H.

1950. Insect Virus. In Viruses 1950. Delbruck, M., ed. California Institute of Technology, Pasadena. 147 pp. (pp. 40-43).

47. Bergold, G. H.

1953. On the nomenclature and classification of insect viruses. Ann. N. Y. Acad. Sci. $56: 495-516$.

48. Bergold, G. H.

1953. The multiplication of insect viruses. In The nature of virus multiplication. Second Symposium of the Society for General Microbiology, Oxford, April 1952. Cambridge University Press, xi-320 pp. (pp. 276-83).

49. BERGOLD, G. H.

1953 (1955). Viruses as organisms, with particular reference to insect viruses. Act. $6^{\mathrm{me}}$ Congr. int. Microbiol., Rome, 3:7-10.

50. Bergold, G. H.

1954. Radioactive experiments with silkworms. For. Insect Invest. [Ottawa] $10(3) 2$.

51. Bergold, G. H.

1957. Über Insektenviren. Nova Acta Leop. Carol. New Ser. 19:109-19.

52. BERGOLD, G. H.

1958. Factors of host cell and environment contributing to masking and latency. Panel discussion (F. C. Bawden, Moderator). In Walker, D. L., R. P. Hanson, and A. S. Evans, eds. 1958. Symposium on latency and masking in viral and rickettsial infections. Burgess Publishing Company, Minneapolis. xi$202 \mathrm{pp}$.

53. BeRGoLD, G. H.

1958. Viruses of insects. In Hallauer, C., and K. F. Meyer, eds. 1958. Handbuch der Virusforschung, 4 (III Ergänzungsband). Springer Verlag, Wien. xv-688 pp. (pp. 60-142).

54. Bergold, G. H., and B. FlaschentRäGER

1957. The polyhedral virus of Prodenia litura (Fabr.) (Lepidoptera: Noctuidae). Nature [Lond.] $180: 1046-47$.

55. Bergold, G. H., and L. Pister

1948. Zur quantitativen Mikrobestimmung von Desoxy- und Ribonucleinsäure. Z. Naturf. 3b:406-10.

56. BERGOLD, G. H., and W. E. RIPPER

1957. The polyhedral virus of Heliothis armigera ( $\mathrm{Hbn}$.$) (Lepidoptera: Noctui-$ dae). Nature [Lond.] 180:764-65.

57. Bergold, G., and G. SCHRAM M

1942. Biochemische Charakterisierung von Insektenviren. Biol. Zbl. 62:105-18. 
58. Bianchi, F. A.

1957. Notes and exhibitions. Proc. Hawaii. ent. Soc. 16:184.

59. ВіLiotтi, E.

1955. Survie des larves endophages de tachinaires à une mort prématurée de leur hôte par maladie. C.R. Acad. Sci. [Paris] 240:1021-23.

60. Biliotiti, E., P. Grison, and D. Martouret

1956. L'utilisation d'une maladie à virus comme méthode de lutte biologique contre Pieris brassicae L. Entomophaga 1:35-44.

61. BiliotTi, E., P. Grison, and C. VAGo

1956. Essai d'utilisation des polyèdres isolés de la processionnaire du pin, comme méthode de lutte biologique contre cet insecte. C.R. Acad. Sci. [Paris] 243: 206-8.

62. BIRD, F. T.

1949. Histopathology and epidemiology of the polyhedral disease of the spruce budworm, Choristoneura fumiferana Clem. For. Insect Invest. [Ottawa]

63. BIRD, F. T. $5(3): 2-3$.

1950. The dissemination and propagation of a virus disease affecting the European pine sawfly, Neodiprion sertifer (Geoff.). For. Insect Invest. [Ottawa] 6(5): $2-3$.

64. BIRD, F. T.

1954. The use of virus diseases against sawflies. Rep. 6th Commonw. ent. Conf., 1954, pp. 122-125.

65. BIRD, F. T.

1954. The use of a virus disease in the biological control of the European spruce sawfly, Diprion hercyniae (Htg.). For. Insect Invest. [Ottawa] 10(1):2-3.

66. BIRD, F. T.

1956 (1958). The use of viruses in the biological control of some forest insects.

67. BIRD, F. T. Proc. 10th int. Congr. Ent., Montreal, $4: 687$.

1957. On the development of insect viruses. Virology 3:237-42.

68. BIRD, F. T.

1958. Histopathology of granulosis in insects. Canad. J. Microbiol. 4:267-72.

69. BIRD, F. T., and D. E. ElgeE

1957. A virus disease and introduced parasites as factors controlling the European spruce sawfly, Diprion hercyniae (Htg.), in Central New Brunswick. Canad.

70. Bolle, J. Ent. $89: 371-78$.

1898. Il giallume o il mal del grasso del baco da seta, una malattia parasitaria. Appendix of La bachicoltura nel Giappone. Giov. Paternolli, Gorizia, 87-129. [This paper was reprinted from a series of articles which appeared in 1897 and 1898 in the Atti Soc. agr. Gorizia. It appeared simultaneously in German (A. Hartleben's Verlag, Wien, 1898, pp. 94-141), as well as in Slovenian and

71. BOLLE, J. Hungarian translations.]

1899. Bericht über die Thätigkeit der k. k. landwirtschaftlich-chemischen Versuchsstation in Görz im Jahre 1898. Z. landw. VersWes. öst. (4). 21 pp.

72. Boudreaux, H. B.

1956. Evidence for a "Virus" affecting morphology in spider mites. Ent. Soc. Am., 73. Bovey, $\mathrm{P}$. 4 th annu. Meeting, New York. Mimeo. 6 pp.

1956 (1958). Le problème de la tordeuse grise du mélèze Eucosma griseana (Hübner) (Lepidoptera: Tortricidae) dans les forêts alpines. Proc. 10th int. Congr. Ent., Montreal, $4: 123-31$.

74. Breed, R. S., and A. Petraitis

1954. Some Russian contributions to taxonomy and nomenclature of the viruses: A review. Int. Bull. bact. Nom. Taxonomy $4: 189-214$. 
75. BREELAND, S. G.

1958. Biological studies on the armyworm, Pseudaletia unipuncta (Haworth), in Tennessee (Lepidoptera: Noctuidae). J. Tenn. Acad. Sci. 33:263-347.

76. BREINDL, V.

1926. Über neue Färbungsmethoden. Zbl. Bakt., Abt. II, 67:370-71.

77. BREINDL, V.

1938. Ergänzende Studie über die Polyedrie der Nonne (L. monacha) und des Schwammspinners (L. dispar). Mem. Soc. zool. tchécosl. 5:94-116.

78. BRun, G., and A. SigoT

1955. Étude de la sensibilité héréditaire au gaz carbonique chez la drosophile. II. Installation du virus dans la lignée germinale à la suite d'une inoculation. Ann. Inst. Pasteur [Paris] 88:488-512.

79. BUCHER, G. E.

1953. Biotic factors of control of the European fir budworm, Choristoneura murinana (Hbn.) (n. comb.), in Europe. Canad. J. agric. Sci. 33:448-69.

80. BUCHER, G. E.

1956 (1958). General summary and review of utilization of disease to control insects. Proc. 10th int. Congr. Ent., Montreal, 4:695-701.

81. Cameron, J. W. MacBain

1952. A survey of investigations on the diseases of insects. Annu. Rep. ent. Soc. [Ontario] 82:7-13.

82. CAPEK, M., R. OBRTEL, and J. WeISER

1958. Choroby, parasiti a episiti judlového obaleče Choristoneura (Cacoecia) murinana Hb. v kalamitní oblasti středního pohroní. (Krankheiten, Parasiten und Episiten des Tannentriebwicklers Choristoneura murinana Hb. im Mittelslowakischen Tannengebiete.) Lesn. Casopis 4:46-70.

83. Carbone, D., and E. Fortuna

1931. La vaccinazione dei bachi da seta. $\mathrm{II}^{\mathrm{a}}$ nota preventiva. Boll. Ist. sieroter. Milano 10:92-102.

84. Chamberlin, F. S., and S. R. Dutkx

1958. Tests of pathogens for the control of tobacco insects. J. econ Ent. 51:560.

85. Clark, E. C.

1954. Biological control of the alfalfa caterpillar. Rep. Alfalfa Improvement Conf. $14: 22-3$.

86. Clark, E. C.

1958. Ecology of the polyhedroses of tent caterpillars. Ecology 39:132-39.

87. Clausen, C. P.

1954. Biological antagonists in the future of insect control. Agric. Food Chem. $2: 12-8$.

88. Clausen, C. P.

1956 (1958). The biological control of insect pests in the continental United States. Proc. 10th int. Congr. Ent., Montreal 4:443-47.

89. COMEL, A.

1950. L'Istituto chimico-agrario sperimentale di Gorizia. 80 anni di sperimentazione agraria. Nuovi Ann. Ist. chim. agr. sper. Gorizia 1:1-250.

90. Conte, A., and D. Levrat

1906. Grasserie des vers à soie. C.R. Ass. franç. Av. Sci. 35 (part 2) :529-33.

91. Cornalia, E.

1856. Monografia del bombice del gelso (Bombyx mori Linneo). Mem. Ist. lombardo $6: 3-387$.

92. DASGUPTA, B., and H. N. RAY

1957. The intranuclear inclusions in the mid-gut of the larva of Anopheles subpictus. Parasitology $47: 194-95$.

93. DAY, M. F., J. L. FARRANT, and CoRAlie Potter

1955. Stages in the development of a polyhedral virus disease. J. appl. Phys. 26: 1396. 
94. DE, M. N.

1911. Grasserie in silk-worms. Agric. J. India 6:292-95.

95. Dikasova, E. T.

1949. Investigation of mulberry silkworm egg mass obtained from the moths affected with yellow disease. Microbiology [Moseow] 18:356-60.

96. Dirks, C. O.

1944. Population studies of the European spruce sawfly in Maine as affected by natural enemies. J. econ. Ent. $37: 238-42$.

97. Dowden, P. B.

1957. Biological control of forest insects in the United States and Canada. J. For. $55: 723-26$.

98. Dowden, P. B., and H. B. GiRTh

1953. Use of a virus disease to control the European spruce sawfly. J. econ Ent. $46: 525-26$.

99. DRILHON, A.

1951. Identification chromatographique et chimique d'une substance fluorescente du sang et du tube de Malpighi de la larve Bombyx mori atteinte de grasserie. C.R. Acad. Sci. [Paris] 232:1876-78.

100. Drilhon, A., C. Vago, and R.-G. Busnel

1952. Essai de diagnostic précoce de la grasserie et de la flacherie par l'analyse chromatographique du sang de Bombyx mori. C.R. Soc. Biol. [Paris] 146: 11-12.

101. Duhamel, Colettte

1954. Étude de la sensibilité héréditaire à l'anhydride carbonique chez la drosophile. Description de quelques variants du virus. C.R. Acad. Sci. [Paris] 239: 1157-9.

102. Duhamel, ColetTe, and Nadine Plus

1956. Phénomène d'interférence entre deux variants du virus de la drosophile. C.R. Acad. Sci. [Paris] 242: 1540-3.

103. Duspiva, F., and G. H. Bergold

1942. Über Peptidase- und Phosphatasebestimmungen im Nonnen-Polyedervirus. Naturwissenschaften $30: 604-5$.

104. Ertogroul, T.

1928. Emploi de la lumière de Wood dans le diagnostic précoce de la grasserie des vers à soie. C.R. Acad. Sci. [Paris] 186:1865-7.

105. ERTOGRoul, T.

1928. Influence favorisante de l'alimentation aux feuilles de murier noir (Morus nigra) sur le developpement de la grasserie du ver à soie. C.R. Soc. Biol.

106. ESCHERICH, K. [Paris] 99:831-2.

1912. Nonnenprobleme. Naturw. Z. Forst- u. Landw. 10:65-85.

107. ESCHERICH, K.

1913. Neues über Polyederkrankheiten. Referierendes und Kritisches. Naturw. Z. Forst- u. Landw. 11:86-97.

108. ESCHERICH, K.

1914. Polyederkrankheiten. In Die Forstinsekten Mitteleuropas. Parey, Berlin. 1: 299-303.

109. ESCHERICH, K.

1931. In Die Forstinsekten Mitteleuropas. Parey, Berlin. 3:78-82, 537, 717.

110. ESCHERICH, K.

1942. In Die Forstinsekten Mitteleuropas. Parey, Berlin. 5:98, 345.

111. Ето, M.

1956. Dissolution of polyhedral protein in alcohol by trichloroacetic acid. Sci. Bull.

112. Ето, M. Fac. Agric. Kyushu Univ. $15: 465-71$.

1956. Behaviour of polyhedral bodies and host cells of silkworms in alcohol. J. Fac. Agric. Kyushu Univ. 10:373-84.

113. Faulkner, P., and G. H. Bergold

1957. Deoxyribonuclease content of an insect virus. Virology 3:603-5. 
114. Fischer, E.

1910. Über die reiffschen Flacherie-Versuche mit der "gipsy moth" (Liparis dispar L.). Ent. Z. [Stuttgart] $24: 47-8$.

115. Forbes, S. A.

1898. Note on a new disease of the army worm (Leucania unipuncta Haworth). 20th Rep. St. Ent., Illinois : 106-9.

116. Francke-Grosmann, $\mathrm{H}$.

1938 (1939). Ein Schimmelpilz als Gelegenheitsparasit der Seidenraupe. Proc. 7th int. Congr. Ent., Berlin, 3:1762-71.

117. Franz, J.

1951. Erfolgreiche Verbreitung von Viruskrankheiten zur Forstschädlingsbekämpfung. Bericht über neuere kanadische Arbeiten. Z. PflKrankh. 58:185-7.

118. Franz, J.

1954.Erfolgreiche Verbreitung einer Virusseuche zur biologischen Bekämpfung

119. Franz, J. der roten Kiefernbuschhornblattwespe. Gesunde Pflanzen 6:173-5.

120. Franz, J.

1956. Die künstliche Verbreitung von Virosen einiger Blattwespen (Diprionidae)

121. Franz, J. innerhalb und ausserhalb ihres Endemiegebietes. Zool. Anz. Suppl. 19:407-12.

1956 (1958). Biological control in Germany. Proc. 10th int. Congr. Ent., Montreal $4: 461-4$.

122. Franz, J.

1957. Bibliographie über biologische Bekämpfung. II. Entomophaga 2:293-311.

123. Franz, J.

1958. Viruskrankheiten zur Bekämpfung schädlicher Blattwespen. (Ein Aufruf). Allg. Forstz. No. 15:215.

124. Franz, J., and A. Krieg

1957. Virosen europäischer Forstinsekten. Z. PflKrankh. 64:1-9.

125. Franz, J., A. Krieg, and R. Langenbuch

1955. Untersuchungen über den Einfluss der Passage durch den Darm von Raubinsekten und Vögeln auf die Infektiosität insektenpathogener Viren. Z. PflKrankh. 62:721-6.

126. Franz, J., and O. F. NikLAS

1954. Feldversuche zur Bekämpfung der roten Kiefernbuschhornblattwespe Neodiprion sertifer (Geoffr.) durch künstliche Verbreitung einer Virusseuche.

127. FYG, W. NachrBl. dtsch. PflSchDienst [Stuttgart] 6:131-4.

1948. Ueber die krankhafte Drohnenbrütigkeit der Bienenkönigin und ihre Ursache. 128. Fyg, W. Schweiz. Bienenztg 71:520-9.

1951. On the various causes of sterility in the queen honeybee. Act. 14th Congr. int.

129. FYG, W. A pic., Leamington. Mimeo. $6 \mathrm{pp}$.

1955. Sind die Drohnen die Überträger der krankhaften Drohnenbrütigkeit der Bienenkönigin? Schweiz. Bienenztg 78:201-4.

130. FYG, W.

1957. Über die verschiedenen Ursachen der Drohnenbrütigkeit. Schweiz. Bienenztg

131. Fyg, W. $80: 154-7,187-92$.

1958. Über die normale und abnorme Entwicklung der Honigbiene. Schweiz. Bienenztg 81:147-54, 194-200, 345-55, 387-98. (English translation in Bee 132. G̈̈BLER, H. World $40: 57-66,85-96 ; 1959$.)

1958. Nonnenmassenvermehrung und -bekämpfung im Gebiet Marienbad (Marianske Lazne)-Karlsbad (Karlovy Vary) in den Jahren 1940 und 1941. Arch. Forstw. 7:729-35. 
133. Gargiulo, F.

1930-31. Nuove ricerche sul giallume del baco da seta. Trattamenti immunizzanti. Boll. Lab. Zool. agr. Bachic. Milano 3:34-52.

134. Gargiulo, F.

1931-32. Ulteriori ricerche sul giallume del baco da seta. Trattamenti immunizzanti. Boll. Lab. Zool. agr. Bachic. Milano 4:103-12.

135. Gershenson, S.

1955. The nature of intranuclear inclusions of polyhedral diseases of insects. C.R. Acad. Sci. U.R.S.S. 104:925-28.

136. GlaSer, R. W.

1917. The growth of insect blood cells in vitro. Psyche [Camb., Mass.] 24:1-7.

137. Glaser, R. W.

1928. Virus diseases of insects. Part I. Sacbrood of honey bees. Part II. The polyhedral diseases. In Rivers, T.M. Filterable Viruses. Williams and Wilkins Co., Baltimore. Pp. 277-331.

138. GLASER, R. W., and J. W. ChapMaN

1912. Studies on the wilt disease or "flacherie" of the gypsy moth. Science 36:219-24.

139. GLASER, R. W. and E. V. CoWDRY

1928. Experiments on the visibility of the polyhedral viruses. J. exp. Med. 47:82934.

140. GLASS, E. H.

1958. Laboratory and field tests with the granulosis of the red-banded leaf roller. J. econ. Ent. 51:454-57.

141. GösswaLD, K.

1934. Zur Biologie und ökologie von Parasetigena segregata Rond. und Sarcophaga Schützei Kram. (Dipt.) nebst Bemerkungen über die forstliche Bedeutung der beiden Arten. Z. angew. Ent. 21:1-23.

142. Grace, T. D. C.

1958. Induction of polyhedral bodies in ovarian tissues of the tussock moth in vitro. Science $128: 249-50$.

143. Grace, T. D. C.

1959. Tissue culture for arthropod viruses. Trans. N. Y. Acad. Sci., Ser. 2, 21:23741.

144. Gratia, A., R. Jeener, and J. Brachet

1945. Teneur en acides nucléiques des granules extraits par ultracentrifugation des tissues de vers à soie normaux et de vers à soie atteints de la "grasserie." C.R. Soc. Biol. [Paris] $139: 76-77$.

145. Gratia, A., and A. Paillot

1938. Caractère antigénique du virus de la grasserie des vers à soie. Ann. Inst. Pasteur [Paris] 61:856-57.

146. Gratia, A., and A. Paillot

1938. Étude sérologique du virus de la grasserie des vers à soie. C.R. Soc. Biol. [Paris] 129:507-9.

147. Gratia, A., and A. Paillot

1939. Étude sérologique du virus de la grasserie des vers à soie isolé par ultracentrifugation. Arch. ges. Virusforsch. 1:130-39.

148. Grison, P.

1956 (1958). Organisation de la lutte biologique en France et résultats obtenus dans l'utilisation des agents pathogènes. Proc. 10th int. Congr. Ent., Montreal, 4:675-79.

149. GRISON, P., and C. VAGO

1953. La régulation des infestations de chenilles processionaires du pin par les maladies à virus. C.R. Acad. Agric. Fr. 39 :485-87.

150. Guillemain, ANnie

1953. Découverte et localisation d'un gène empêchant la multiplication du virus de la sensibilité héréditaire au $\mathrm{CO}_{2}$ chez Drosophila melanogaster. C.R. Acad. Sci. [Paris] 236:1085-86. 
151. GÜNTHER, $\mathrm{S}$.

1956. Zur Infektion des Goldafters (Euproctis chrysorrhoea L.) mit Plistophora schubergi Zwölfer (Microsporidia). Z. angew. Zool. 43:397-405.

152. GÜNTHER, $\mathrm{S}$.

1958. Eine bisher unbekannte Mikrosporidie aus dem Ringelspinner (Malacosoma neustria L.; Lasiocampidae). Z. PflKrankh. 65 :534-35.

153. GÜNTHER, S.

1958. Forschungsarbeiten über Infektionskrankheiten bei Forstinsekten als Ergänzung zu gradologischen Untersuchungen. Forst und Jagd 8:208.

154. GYRISCO, G. G.

1958. Forage insects and their control. Annu. Rev. Ent. 3:421-41.

155. HABERLANDT, F.

1872. Il giallume. Seric. austriaca [Gorizia] 4:49-52.

156. HALL, I. M.

1955. The use of Bacillus thuringiensis Berliner to control the western grapeleaf skeletonizer. J. econ. Ent. 48:675-77.

157. HaLL, I. M.

1957. Use of a polyhedrosis virus to control cabbage looper on lettuce in California. J. econ. Ent. $50: 551-53$.

158. HARNISCH, $\mathrm{O}$.

1949. Beobachtungen an virus-kranken Larven von Chironomus (Camptochironomus) tentans Fabr. Experientia 5:205-6.

159. HARVILLE, J. P.

1955. Ecology and population dynamies of the California oak moth, Phryganidia californica Packard (Lepidoptera: Dioptidae). Microentomology $20: 83-166$.

160. HEIDENREICH, E.

1938 (1939). Untersuchungen an Viruskrankheiten einiger Forstinsekten. Proc. 7th int. Congr. Ent., Berlin, 3:1963-73.

161. Henze, O.

1935. Über die Wirkung strömender Luft auf die Entwicklung von Lepidopteren. Z. angew. Ent. 21:385-405.

162. Holoway, C. F., and G. H. Bergold

1953. Iron content of an insect virus. Science 117:251-52.

163. Holow AY, C. F., and G. H. Bergold

1955. Determination of magnesium in an insect virus. Science $122: 1266-67$.

164. Huger, A., and A. KRIEG

1958. Über eine Cytoplasma-Polyedrose der Nonnenraupe (Lymantria monacha L.). Naturwissenschaften 45:170-71.

165. HUGHES, K. M.

1953. Conservation of the generic name Borrelina and designation of the type species. Int. Bull. bact. Nom. Taxonomy 3:134-37.

166. Hughes, K. M.

1957. An annotated list and bibliography of insects reported to have virus diseases. Hilgardia 26(14) :597-629.

167. HuGHES, K. M.

1958. The question of plurality of virus particles in insect-virus capsules and an attempt at clarification of insect virus terminology. Trans. Amer. micr. Soc. $77: 22-30$.

168. Husson, R.

1956 (1958). Les ennemis naturels de l'Ennomos quercinaria (Hufn.) lors de sa

169. IKEDA, $\mathrm{H}$. recente pullulation on Sarre. Proc. 10th int. Congr. Ent., Montreal, 4:437-40.

1951. Biochemical studies on the polyhedra of the silkworm (Bombyx mori L.) grasserie. I. Elementary analyses and ultraviolet absorption spectra of the polyhedra. J. sci. Res. Inst. [Tokyo] 45:217-25.

170. IrWin, MargareT C.

1947. The California oak moth. Santa Barbara Museum of Natural History, Special Bull. 2:1-7. 
171. IsHIMORI, $\mathrm{N}$.

1934. Contribution à l'étude de la grasserie du ver à soie (Bombyx mori). C.R. Soc. Biol. [Paris] 116:1169-70.

172. IsHIMORI, N.

1935. Silkworm jaundice in relation to the midgut epithelium and cellular destruction. Bot. \& Zool. [Tokyo] 3:10-14.

173. Iwashita, Y., and H. ArUga

1957. Mechanism of resistance to virus diseases in the silkworm, Bombyx mori. III. Histological studies on the polyhedroses in the silkworm. J. seric. Sei. [Tokyo] $26: 323-28$.

174. JAHN, ELSE

1949. Die Polyederkrankheit des grauen Lärchenwicklers. PflSchBer. 3:33-41.

175. JAHN, ELSE

1954. Weitere Beobachtungen zur Natur von Insektenviren an Hand von elektronenmikroskopischen Untersuchungen. Anz. Schädlingsk. 27:17-25.

176. JAHN, ELSE

1956. Stellungnahme zur Arbeit von A. Krieg (1955): “Zur Differentialdiagnose von Viruskrankheiten bei Insekten" (Bemerkungen zu Arbeiten von E. Jahn). Mikroskopie $11: 233-34$.

177. JAHN, ELSE

1958. Geregelte Anordnung von Polyederviren in Insektenpolyedern im Zusammenhang mit deren Umbildung zu bandförmigen Formen. Anz. Schädlingsk. $31: 1-4$.

178. JAHN, ELSE

1958. Insektenviren. Probleme der Bioklimatologie, Vol. 4. Akademische Verlagsgesellschaft Geest und Portig K.-G., Leipzig. xii-200 pp.

179. JAHN, ELSE

1958. Probleme zu festgestellten Veränderungen von Polyederkörpern bei Insektenviruserkrankungen. Mikroskopie 12:301-4.

180. JAHN, ELSE

1958. Zusammenfassender Bericht über das Massenauftreten des Grauen Lärchenwicklers in den Jahren 1954-1957 (mit genauen Untersuchungsgrundlagen). Zbl. ges. Forstw. 75 :77-105.

181. JAHN, Else, and A. Sinreich

1957. Zum Auftreten des Kiefernspanners, Bupalus piniarius L. im Burgenland in den Jahren 1952-1956. Z. angew. Ent. 41:184-95.

182. JANisch, E.

1936. Physiologische Grundlagen der Nonnenprognose. Anz. Schädlingsk. 12:77-82.

183. JANISCH, E.

1941. Über die Bewertung der Mortalitätsfaktoren beim Massenwechsel von Schadinsekten. Z. angew. Ent. $28: 241-53$.

184. JANISCH, E.

1942. Mischinfektionen bei Nonnenraupen. Arb. physiol. angew. Ent. Berl. 9:185-202.

185. JANISCH, E.

1958. Nachträge zum Problem des Polyedervirus bei Insektenkrankheiten. Z. angew. Ent. 42:292-306.

186. JANISCH, E.

1958. Populationsanalyse bei Schadinsekten. Z. angew. Ent. 43:371-86.

187. JoNEs, H. N.

1910. Further studies on the nature of the wilt disease of the gypsy moth larvae. 7th Annu. Rep. St. For., Massachusetts, No. 73:101-5.

188. JUCCI, C.

1942. Ricerche sul bombice del ricino Phyosamia ricini. Ann. Afr. ital. 2:447-67. 189. KaramaN, Z.

1958. Beobachtungen zum Auftreten der Nonne (Lymantria monacha L.) 1955/56 in den Buchenwälder Westmazendoniens, Jugoslavien. Z. angew. Ent. $42: 236-$ 38. 
190. Klug, A., Rosalind E. Franklin, and S. P. F. Humphreys-Owen

1959. The crystal structure of Tipula iridescent virus as determined by Bragg reflection of visible light. Biochim. biophys. Acta 32:203-19.

191. KNoche, E.

1912. Nonnenstudien. Naturw. Z. Forst -u. Landw. 10:85-138.

192. KoMÁREK, J.

1921. Kalamita minisková a polyedrická nemoc. (The polyhedral disease of nun-moth caterpillars.) Acta Soc. ent. Bohem. (Čsl.) 18:6-10.

193. KovaČEvić, ž.

1954. Značaj poliedrije za masovnu pojavu nekih insekata (The importance of the polyhedry for the mass appearance of some insects.) Zasht. Bilja No. 23:3-20.

194. KovaČEviĆ, ž.

1956. Die Nahrungswahl und das Auftreten der Pflanzenschädlinge. Anz. Schädlingsk. $29: 97-101$.

195. KovaČEvić, ž.

1957. Nahrungswahl und Vermehrungspotential einiger schädlichen Schmetterlingsarten. Symposium "Insect and Foodplant", Wageningen, 1957, pp. 117-18.

196. KovaČEvić, ž.

1958. Pathogene Mikroorganismen als Begleiter und Mortalitätsfaktoren des Schwammspinners Lymantria dispar L. und des amerikanischen Webebären Hyphantria cunea Drury. Anz. Schädlingsk. 31:148-50.

197. KRASSILSCH'SCHIK, J.-M.

1896. Sur une nouvelle proprieté du corpuscule (Microsporidium) de la pébrine. C.R. Acad. Sci. [Paris] $123: 358-59$.

198. Krassilscht'schiK, J.-M.

1896. Sur les microbes de la flacherie et de la grasserie des vers à soie. C.R. Acad. Sci. [Paris] 123:427-29.

199. KrassilschtschiK, J.-M.

1896. Sur les parasites des vers à soie sains et malades. Contribution à l'étude de la flacherie, de la grasserie et de la pébrine. Mém. Soc. zool. Fr. 9:513-22.

200. KRIEG, A.

1955. Die Virus-Seuche der roten Kiefernbuschhornblattwespe, Neodiprion sertifer Geoffr. Mitt. biol. ZentAnst. Berl. No. 83:92-95.

201. KrIEG, A.

1955. Untersuchungen über die Polyedrose von Neodiprion sertifer (Geoffr.). Arch. ges. Virusforsch. 6:163-74.

202. KRIEG, A.

1955. Zur Frage einer "künstlichen Virus-Erzeugung" in Bombyx mori L. Naturwissenschaften 42:589-90.

203. KRIEG, A.

1955. Zur Differentialdiagnose von Viruskrankheiten bei Insekten. Mikroskopie 10:258-62.

204. KRIEG, A.

1956. "Endogene Virusentstehung" und Latenz-problem bei Insektenviren. Untersuchungen zer Polyedrose von Neodiprion sertifer (Geoffr.). II. Mitteilung. Arch. ges. Virusforsch. 6:472-81.

205. KRIEG, A.

1956. Virus-Isolierung aus kranken Larven von Hibernia defoliaria L. und Euproctis chrysorrhoea L. Naturwissenschaften 43 :260-61.

206. KRIEG, A.

1956. Über die Nucleinsäuren der Polyeder-Viren. Naturwissenschaften 43:537.

207. KRIEG, A.

1956. Erwiderung auf eine Stellungnahme von E. Jahn (1956). Mikroskopie 11:23536.

208. KRIEG, A.

1956 (1958). Latente und akute Infektionen mit Insekten-Viren. Proc. 10th int. Congr. Ent., Montreal, $4: 737-40$. 
209. Krieg, A.

1957. Eine Polyedrose von Aporia crataegi L. (Lepidoptera). (Zugleich ein Beitrag über den atypischen Verlauf von Insekten-Virosen.) II. Mitteilung. Z. PflKrankh. 64:657-62.

210. KRIEG, A.

1957. "Toleranzphänomen" und Latenzproblem. III. Mitteilung: Untersuchungen über die Polyedrose von Neodiprion sertifer (Geoffr.). Arch. ges. Virus-forsch. 7:212-19.

211. KRIEG, A.

1957. Über Aufbau und Vermehrungsmöglichkeiten von stäbchenförmigen InsektenViren Z. Naturf. 12b:120-21.

212. KRIEG, A.

1957. Zur Differentialdiagnose von Viruskrankheiten bei Insekten. II. Mitteilung. Mikroskopie 12:110-17.

213. KRIEG, A.

1958. Verlauf des Infektionstiters bei stäbchenförmigen Insekten-Viren. Z. Naturf. 13b:27-29.

214. Krieg, A., and R. LANGenbuch

1956. Über eine Polyedrose von Dasychira pudibunda L. (Lepidoptera, Lymantriidae). Arch. ges. Virus-forsch. $7: 18-27$.

215. KRYWienczYK, J., D. R. MACGRegor, and G. H. Bergold

1958. Serological relationships of viruses from some lepidopterous insects. Virology $5: 476-80$.

216. LANGENBUCH, R.

1957. Beitrag zur Differentialdiagnose von Viruseinschlusskörpern (Polyedern) in Schnittpräparaten. Z. PfiKrankh. 64:443-44.

217. LANGENBUCH, R.

1957. Beitrag zur Färbung von Einschlusskörpern (Polyedern) in Blut- und Gewebeausstrichen viruskranker Insekten. Mikroskopie 12:267-68.

218. LANGSTON, R. L.

1957. A synopsis of hymenopterous parasites of Malacosoma in California (Lepidoptera, Lasiocampidae). Univ. Calif. Publ. Ent. 14:1-50.

219. LAUFFER, M. A.

1943. Ultracentrifugation studies on the blood of normal and jaundice-diseased silkworms. Proc. Soc. exp. Biol. [N.Y.] 52:330-32.

220. LEGENDRE, A.-F.

1913. L'élevage des vers à soie dans la haute vallée du Yalong (Kientchang). Ann. Éc. Agric. Montpellier 13:71-112.

221. De Lestrange, Marie-Thérèse

1954. Action de la temperature sur le virus responsable de la sensibilité à l'anhydride carbonique chez la drosophile. C.R. Acad. Sci [Paris] 239:1159-62.

222. LETJE, W.

1938 (1939). Mitteilungen zur Ätiologie und Pathologie der Gelbsucht der Seiden-

223. L'HÉritier, $P$. raupen. Proc. 7th int. Congr. Ent., Berlin, 3:1830-44.

1948. Sensitivity to $\mathrm{CO}_{2}$ in Drosophila-a review. Heredity 2:325-48.

224. L'HERITIER, $P$.

1951. The $\mathrm{CO}_{2}$ sensitivity problem in Drosophila. Cold Spr. Harb. Symp. quant. Biol. 16:99-112.

225. L'HERITIER, $P$.

1955. Les virus intégrés et l'unité cellulaire. Ann. Biol. [Paris] 31:481-96.

226. L'HERITIER, P.

1958. The hereditary virus of Drosophila. Advanc. Virus Res. 5:195-245.

227. L'HEritier, P., and Nadine Plus

1950. Inactivation par les rayons $X$ du virus responsable de la sensibilité au $\mathrm{CO}_{2}$ chez la drosophile. C.R. Acad. Sci. [Paris] 231:192-94.

228. L'Héritier, P., and G. Teissier

1937. Une anomalie physiologique héréditaire chez la drosophile. C.R. Acad. Sci. [Paris] 205:1099-1101. 
229. Luria, S. E.

1953. General virology. Wiley and Sons, Inc., New York. xiv-427 pp.

230. McEwen, F. L., and G. E. R. Hervey

1958. Control of the cabbage looper with a virus disease. J. econ. Ent. 51:626-31.

231. MACHAY, L.

1956. Az amerikai fehér szövölepke irtása vírussal. Agrártudomány 8:349-50.

232 MACHAY, L., and B. Lovas

1954. Electron microscopic studies on the alkalic dissolution of polyhedral inclusion bodies. Acta vet. hung. 4:253-58.

233. MACHAY, L., and B. Lovas

1955. Polyeder zárványtestek oldódásának elektronmikroszkópos vizsgálata. (Electron microscopic study of polyhedral inclusion bodies during dissolution.) Biol. Közlemények 3:59-65.

234. MachaY, L., and B. Lovas

1955. Der Erreger der Viruskrankheit von Hyphantria cunea Drury. Acta microbiol. Acad. Sci. Hung. 3:117-24.

235. Machay, L., and B. Lovas

1957. Az amerikai fehér szövölepke, Hyphantria cunea Drury magyarországi vírusáról és e vírussal folytatott fertözési kísérletek eredményeiröl. (Histological, electronmicroscopic and epizootical studies on a virus isolated from the larvae of the Hyphantria cunea Drury.) Biol. Közlemények 5:7-18.

236. Maestri, A.

1856. Frammenti anatomici, fisiologici e patologici sul baco da seta (Bombyx mori Linn.). Fratelli Fusi, Pavia. 172 pp.

237. Manunta, C.

1940. Saggi preliminari sui corpuscoli poliedrici del giallume dei bachi da seta. R. C. Ist. lombardo 73 (Ser. 3,4 ) : 443-450.

238. Marcovitch, $\mathrm{S}$.

1958. Some climatic relations of armyworm outbreaks. J. Tenn. Acad. Sci. 33:34850.

¿39. Martignoni, M. E.

1955. Microinjector needle for determination of per os-LD 50 of insect viruses. Science 122: 764 .

240. Martignoni, M. E.

1958. Exploring new methods for mass production of insect viruses. Pest Contr. Rev., Univ. Calif. Agricultural Extension Service, July 1958. P. 8.

241. Martignoni, M. E., and C. Auer

1957. Bekämpfungsversuch gegen Eucosma griseana (Hübner) (Lepidoptera, Tortricidae) mit einem Granulosis-Virus. Mitt. schweiz. Anst. forstl. Versuchsw. 33:73-93.

242. MASERA, E.

1936. Le malattie infettive degli insetti e loro indice bibliografico. Licinio Cappelli, Bologna. 343 pp.

243. MASERA, E.

1937. I germogli di gelso in relazione alla poliedria del baco da seta. Annu. Staz. bacol. sper. Padova $49: 240-45$.

244. MASERA, E.

1948. Le malattie del baco da seta in Italia. Sulle malattie del Bombyx mori L. Act. 7me Congr. int. Seric., Alès, 521-34. (Complete French translation : 535-49.)

245. MASERA, E.

1952. Ricerche sulla poliedria del Bombyx mori L. Rev. Ver à Soie 4:37-46.

246. MASERA, E.

1957. Effetti dell'arricchimento dell'alimento del baco da seta con il latte. Terra friulana, Nos. 1 and 2, 15 pp.

247. MASERA, E.

1957. Patologia del baco da seta. In Schemi delle lezioni di aggiornamento in bachicoltura per ispettori agrari. Borghero, Padova. Pp. 57-65.

248. MEnegaux, A.

1899. Sur la grasserie du ver à soie d'après le travail de Bolle. Bull. sci. Fr. Belg. 32:201-19. 
249. MEYER, G.

1955. Die "Gelbsucht" der Seidenraupen. Mikrokosmos 44:250-54.

250. Morgan, C., G. H. Bergold, and H. M. Rose

1956. Use of serial sections to delineate the structure of Porthetria dispar virus in the electron microscope. J. biophys. biochem. Cytol. 2:23-28.

251. MoRIson, G. D.

1938 (1939). Bee paralysis of the honey-bee (Apis mellifica L.). Proc. 7th int. Congr. Ent., Berlin, 3:1851-56.

252. Morris, R. F., C. A. Miller, D. O. Greenbank, and D. G. MotT

1956 (1958). The population dynamics of the spruce budworm in eastern Canada. Proc. 10th int. Congr. Ent., Montreal, 4:137-49.

253. Murai, S., and K. Aizawa

1957. Dehydrogenase activity in the jaundice-diseased silkworm, Bombyx mori. Sanshi-kenkyu 19:12-14.

254. NeILson, M. M.

1956. Disease in spruce budworm adults. For. Insect Invest. [Ottawa] 12(6):1-2.

255. NeILSON, M. M.

1959. Trials of an introduced polyhedral virus against the European winter moth (Operophtera brumata Linn.) and the fall cankerworm (Alsophila pometaria Harr.) - a preliminary report. Inter. Rep. 1957-10, For. Biol. Lab., Fredericton, Can. Dept. Agric. 19 pp.

256. NeIlson, M. M., and D. B. Marks

1956. Laboratory trials of an introduced polyhedral disease from larvae of the painted lady butterfly (Vanessa cardui L.) against larvae of the European winter moth (Operophtera brumata L.) and the fall cankerworm (Alsophila pometaria Harr.). Inter. Rep. 1955-3, For. Biol. Lab., Fredericton, Can. Dept. Agric. $11 \mathrm{pp}$.

257. NikLAS, O.-F.

1942. Zum Massenwechsel der Tachine Parasetigena segregata Rond. in der Rominter Heide. Monogr. angew. Ent. No. 15:319-58.

258. Ossowski, L. L. J.

1957. The biological control of the wattle bagworm (Kotochalia junodi Heyl.) by a virus disease. Ann. appl. Biol. 45:81-89.

259. Ossowski, L. L. J.

1957. Notes on wattle insects observed during the period 1956-1957. Wattle Res. Inst. Rep., 1956-1957:29-32.

260. Ossowski, L. L. J.

1957. Über Kotochalia junodi (Heyl.)-Psychidae-einen Grosschädling in Schwarzakazienwäldern von Südafrika. Z. angew. Ent. 41:139-52.

261. Ossowski, L. L. J.

1958. On the virus causing polyhedral wilt disease of the wattle bagworm, Kotochalia junodi (Heyl.). S. Afr. J. Sci. 54:75-76.

262. Ossowski, L. L. J.

1958. Occurrence of strains of the nuclear polyhedral virus of the wattle bagworm. Nature 181:648.

263. Paillot, A.

1916. Les microorganismes parasites des insectes. Leur emploi en agriculture. Ann. Épiphyt. 2:188-232.

264. Paillot, A.

1925. La grasserie chez les papillons du ver à soie. C.R. Acad. Agric. Fr. 11:858-60.

265. PaIllot, A.

1925. Sur les altérations cytologiques au cours de l'évolution de la maladie du noyau des chenilles de Pieris brassicae L. C.R. Acad. Sci. [Paris] 180:1797-99.

266. Paillot, A.

1925. Sur les altérations cytoplasmiques et nucléaries au cours de l'évolution de la grasserie du ver à soie. C.R. Acad. Sci. [Paris] 180:1139-42.

267. Paillot, A.

1925. Sur la grasserie du ver à soie. C.R. Acad. Sci. [Paris] 181:306-8. 
268. PaILlot, A.

1926. Existence de la grasserie chez les papillons du ver à soie. C.R. Acad. Agric. Fr. 12:57-63.

269. Paillot, A.

1926. Sur la flacherie du ver à soie et ses causes. C.R. Acad. Sci. [Paris] 183:402-4.

270. PaIllot, A.

1926. Sur la flacherie du ver à soie. C.R. Soc. Biol. [Paris] 95:1370-72.

271. Paillot, A.

1927. Étude sur la grasserie (polyédrie) et les maladies du tube intestinal $d u$ Bombyx du mûrier. Congr. europ. Soie, Milan. 18 pp.

272. Paillot, A.

1927. Sur la gattine expérimentale du ver à soie. C.R. Acad. Sci. [Paris] 184:705-7.

273. Paillot, A.

1927. Sur l'anatomo-pathologie de la grasserie du ver à soie. C.R. Soc. Biol. [Paris] $96: 550-51$.

274. Paillot, A.

1927. Sur l'épidémiologie de la gattine du ver à soie et de la flacherie vraie ou flacherie de Pasteur. C.R. Soc. Biol. [Paris] 97:766-68.

275. Paillot, A.

1927. Vue d'ensemble sur les affections du tube digestif du ver à soie. Méthodes pratiques pour les éviter. C.R. Acad. Agric. Fr. 13:150-55.

276. PAILlOT, A.

1928. Les maladies du ver à soie. Editions du Service Photographique de l'Université, Lyon. 328 pp.

277. Paillot, A.

1929. La gattine et la flacherie vraie ou flacherie de Pasteur, maladies infectieuses mixtes à ultra-microbe et bactéries. C.R. Acad. Sci. [Paris] 189:308-10.

278. Paillot, A.

1931. La grasserie et les dysenteries du Bombyx du mûrier. Rapp. Lab. Soie [Lyon] $17: 105-23$.

279. PAILlot, A.

1931. Sur la gattine du ver à soie. C.R. Acad. Sci. [Paris] 193:211-13.

280. PaIllot, A.

1933. L'infection chez les insectes. Immunité et symbiose. Imprimerie G. Patissier, Trévoux. $535 \mathrm{pp}$.

281. Paillot, A.

1936. Nouveau type de maladies à polyèdres ou polyédries observé chez les chenilles d'Euxoa (Agrotis) segetum Schiff. C.R. Acad. Sci. [Paris] 202:254-56.

282. Paillot, A.

1941. Sur les variations du cytotropisme des ultravirus. C.R. Acad. Agric. Fr. $27: 476-78$.

283. Paillot, A., and A. Gratia

1938. Application de l'ultracentrifugation à l'isolement du virus de la grasserie des vers à soie. C.R. Soc. Biol. [Paris] 128:1178-80.

284. Paillot, A., and A. Gratia

1938. Ultracentrifugation du virus de la grasserie des vers à soie. Ann. Inst. Pasteur [Paris] 61:857-58.

285. Panebianco, $R$.

1895. Osservazioni sui granuli del giallume. Boll. Bachic. [Padova], Ser. 2, 12:14560.

286. Panebianco, R.

1903. Ancora sui cristalli di giallume. Riv. Min. ital. 29:90.

287. PARDI, L.

1939. I corpi grassi degli insetti. Redia 25:87-288.

288. PERRoncito, E.

1902. Il coccidio jalino (Coccidium jalinum n. sp.) ed il microsporidio poliedrico (Microsporidium polyedricum Bolle) nell'uomo. G. Accad. Med. Torino 65:378. 
289. Plus, Nadine

1955. Etude de la sensibilité héréditaire au $\mathrm{CO}_{2}$ chez la drosophile. I. Multiplication du virus $\sigma$ et passage à la descendance après inoculation ou transmission 290. Plus, NADiNe héréditaire. Ann. Inst. Pasteur [Paris] 88:347-63.

1956 (1958). Le virus non pathogène de la drosophile, son intégration au système génétique de la mouche. Proc. 10th int. Congr. Ent., Montreal, 4:741-42.

291. Prebble, M. L.

1956. Virus and other diseases of forest insects in Canada. 12me Congr. Un. int. Rech. for., Oxford. Mimeo. $6 \mathrm{pp}$.

292. PRELL, H.

1925 (1926). Die Polyederkrankheiten der Insekten. Proc. 3rd int. Congr. Ent., Zürich, 2:145-68.

293. von ProwazeK, $\mathrm{S}$.

1912. Untersuchungen über die Gelbsucht der Seidenraupen. Zbl. Bakt., Abt. I, 67:268-84.

294. RABB, R. L.

1958. Living insecticides. Res. \& Fmg N.C. 17(1):8-9.

295. RASEK, J. M.

1930. Presidential address, discussion. J. econ. Ent. 23:37-38.

296. Reboulllon, A.

1925. Sur la sélection macroscopique et microscopique des papillons de vers à soie du mûrier (Sericaria mori) atteints de la maladie de la "grasserie." C.R. Acad. Agric. Fr. 11:744-48.

297. ReBouillon, A.

1926. À propos de l'existence de la grasserie chez les papillons de vers à soie. C.R. Acad. Agric. Fr. 12:201-4.

298. REIFF, W.

1911. The wilt disease, or flacherie, of the gypsy moth. Contr. ent. Lab. Bussey Inst. Harv. No. 36: $60 \mathrm{pp}$.

299. REIFF, W.

1913. Zur Escherich'schen Auslegung meiner Arbeit über die "Wilt disease" des 300. RICHARDS, O. W.

Schwammspinners (Liparis dispar L.). Naturw. Z. Forst- u. Landw. 11:49-54.

1940. The biology of the small white butterfly (Pieris rapae) with special reference to the factors controlling its abundance. J. Anim. Ecol. 9:243-88.

301. RichmoND, H. A.

1948. Hemlock looper disease studies. For. Insect Invest., Ottawa, 4 (4) :4.

302. Riley, C. V.

1886. The mulberry silk-worm; being a manual of instructions in silk-culture. U. S. Dept. Agric. Div. Ent. Bull. 9, 6th rev. ed., pp. 11-61.

303. ROEGNER-AUST, SOPHIA

1947. Der Infektionsweg bei der Polyederkrankheit der Nonne. Naturwissenschaften $34: 158-59$.

304. ROEGNER-AUST, SOPHIA

1949. Populationsanalytische Untersuchungen über die Sterblichkeit von Nonnen-

305. Rost, H. raupen. Z. angew. Ent. 31:181-207.

1955. Untersuchungen und Beobachtungen über Infektionskrankheiten bei Seidenraupen. Arch. Geflügelz. Kleintierk. 4:241-55.

306. RUSKa, H.

1950. Die Elektronenmikroskopie in der Virusforsehung. In Doerr, R., and C. Hallauer. 1950. Handbuch der Virusforschung, 3 (II. Ergänzungsband). Springer 307. RŮžIČKA, J. Verlag, Wien. viii-425 pp. (pp. 221-417).

1924. Die neuesten Erfahrungen über die Nonne in Böhmen. Zbl. ges. Forstw. 50:3368. 
308. SACCHI, $R$.

1933. Ricerche sulla vaccinazione del baco da seta nella lotta contro il "giallume." Boll. Ist. sieroter. Milano 12:679-84.

309. SAGER, S. M.

1955. Virus disease in Western tent caterpillar (Malacosoma pluviale). For. Insect 310. SAGER, S. M. Invest., Ottawa, 11(2):3.

1957. A virus disease of western hemlock looper, Lambdina fiscellaria lugubrosa (Hulst) (Lepidoptera: Geometridae). Canad. J. Microbiol. 3:799-802.

311. SAGER, S. M.

1958. Studies on the epizootiology of a virus disease in the douglas-fir tussock moth (Hemerocampa pseudotsugata McD.). Inter. Rep. 1955-6, For. Biol. Lab., Victoria, Can. Dep. Agric. 27 pp.

312. SCHEDL, K. E.

1949. Erfahrungen und Beobachtungen anlässlich der Nonnengradation in der Steiermark in den Jahren 1946 bis 1948. Verlag Ferd. Kleinmayr, Klagenfurt. $129 \mathrm{pp}$.

313. SCHMIDT, LEA

1956. Utjecaj hrane na razvoj gubara (Lymantria dispar L.). [The influence of food on the development of gipsy-moth (Lymantria dispar L.).] Ann. Exp. for. [Zagreb] 12:105-66.

314. SCHMIDT, LFA, and G. PhILIPS

1958. Granuloza-nova virusna bolest na dudoveu (Hyphantria cunea Drury). (Granulosis-a new virus disease of the fall webworm.) Fac. Agric. For., Inst. Ent. [Zagreb] No. 1.27 pp.

315. Schoene, W. J., and NANNiE V. Sibold

1952. A virus disease of the red-banded leaf roller. J. econ. Ent. 45:1081.

316. Schramm, G.

1954. Die Biochemie der Viren. Springer-Verlag, Berlin. viii-276 pp. (Insektenviren: pp. 184-95).

317. Schramm, G.

1958. Biochemistry of viruses. Annu. Rev. Biochem. 27:101-36.

318. SEMEL, MAURIE

1956. Polyhedrosis wilt of cabbage looper on Long Island. J. econ. Ent. 49:420-21.

319. Sibold Long, Nannie

1953. Life history of the red-banded leaf roller. Tech. Bull. Va. agric. Exp. Sta. No. $120.18 \mathrm{pp}$.

320. SIPPELL, W. L.

1952. Winter rearing of the forest tent caterpillar, Malacosoma disstria Hbn. For. Insect Invest. [Ottawa] 8(4):1-2.

321. SKaIFE, S. H.

1921. Some factors in the natural control of the wattle bagworm. S. Afr. J. Sci. $17: 291-301$.

322. SMITH, J. D., and G. R. WYATT

1951. The composition of some microbial deoxypentose nucleic acids. Biochem. J. 49:144-48.

323. Sмiтн, K. M.

1951. The polyhedral diseases of insects. Endeavour 10:194-99.

324. SMITH, K. M.

1952. Latency in viruses and the production of new virus diseases. Biol. Rev.

325. SмITH, K. M. $27: 347-57$.

1954. Viruses and the control of insect pests. Discovery 15:455-58.

326. SмIтн, K. M.

1954. Viruses and the electron microscope. Roy. Coll. Sci., Sci. J., 24:66-70.

327. SмITH, K. M.

1955. Morphology and development of insect viruses. Advanc. Virus Res. 3:199-220. 
328. SмIтH, K. M.

1955. What is a virus? Nature [Lond.] 175:12-15.

329. SмITH, K. M.

1956. The structure of insect virus particles. J. biophys. biochem. Cytol. 2:301-11. 330. SмIтH, K. M.

1956. Virus diseases of insects-their use in biological control. Agriculture 63:27175.

331. SмIтH, K. M.

1958. The morphology and erystallization of insect cytoplasmic viruses. Virology $5: 168-71$.

332. Sмiтh, K. M.

1958. Early stages of infection with the Tipula iridescent virus. Nature [Lond.] 181:966-67.

333. Sмiтh, K. M.

1958. A study of the early stages of infection with the Tipula iridescent virus. Parasitology 48:459-62.

334. SMith, K. M., and C. F. Rivers

1957. The polyhedral virus of Heliothis armigera (Hbn.). Nature [Lond.] 180:928.

335. Sмiтh, K. M., and R. C. Williams

1958. Insect viruses and their structure. Endeavour 17:12-21.

336. SMith, K. M., and N. Xeros

1953 (1955). Cross-inoculation studies with polyhedral viruses. 6me Congr. int. Microbiol., Rome, 6th Symposium (Interaction of viruses and cells): 81-96; Symposia, summaries: $185-86$.

337. SNYDER, K. D.

1951. The biology of the variegated cutworm Peridroma saucia Hübner with special reference to the effect of temperature and food on development. Ph.D. Thesis

338. SPEYER, W. in Entomology, University of California, Berkeley. $92 \mathrm{pp}$.

1925. Beitrag zur Wirkung von Arsenverbindungen auf Lepidopteren. Z. angew. Ent. 11:395-99.

339. Steinhaus, E. A.

1956 (1958). Stress as a factor in insect disease. Proc. 10th int. Congr. Ent., Montreal, 4:725-30.

340. Steinhaus, E. A.

1957. Microbial diseases of insects. Annu. Rev. Microbiol. 11:165-82.

341. Steinhaus, E. A.

1958. Crowding as a possible stress factor in insect disease. Ecology 39:503-14.

342. Steinhaus, E. A.

1959. Insect pathology and microbial control. Pest. Contr. Rev., Univ. Calif. Agricultural Extension Service, Feb. $1959: 1-3$.

343. Steinhaus, E. A.

1959. Granuloses in two Alaskan insects. J. econ. Ent. 52:350-52.

344. Steinhaus, E. A., and C. G. Thompson

1949. Alfalfa caterpillar tests (biological control by artificial spread of virus disease studied). Calif. Agric. 3(3):5-6.

345. Steinhaus, E. A., and C. G. Thompson

1949. Preliminary field tests using a polyhedrosis virus to control the alfalfa cater pillar. J. econ. Ent. 42:301-5.

346. StellwaAG, F.

1924. Der Baumweissling Aporia crataegi L. Z. angew. Ent. 10:273-312.

347. STRUBLE, G. R.

1956. Biology and control of the logepole needle miner. Progress report of 1955 studies. Calif. For. \& Range Exp. Sta., U. S. Dep. Agric., Berkeley. Mimeo. $29 \mathrm{pp}$.

348. SWeEtman, H. L.

1956 (1958). Successful biological control against animals. Proc. 10th int. Congr. Ent., Montreal, 4:449-59. 
349. SWEETMAN, H. L.

1958. The principles of biological control. Interrelation of hosts and pests and utilizazation in regulation of animal and plant populations. Wm. C. Brown Co., Inc., Dubuque, Iowa. xii-560 pp.

350. Szirmai, J.

1957. Biologische Abwehr mittels Virus zur Bekämpfung der Hyphantria cunea Drury. Acta microbiol. Acad. Sci. Hung. 4:31-42.

351. TANada, $Y$.

1956. Microbial control of imported cabbageworm. Hawaii Fm Sci. 4(3):6-7.

352. TANADA, $\mathrm{Y}$. 1959. Microbial control of insect pests. Annu. Rev. Ent. 4:277-302.

353. TANADA, Y., and J. W. Beardsley, JR.

1958. A biological study of the lawn armyworm, Spodoptera mauritia (Boisduval), in Hawaii (Lepidoptera: Phalaenidae). Proc. Hawaii. ent. Soc. 16:411-36.

354. Tarassevich, L. M.

1946. On the nucleic acids of the polyhedra of the mulberry silkwork. Microbiology [Moscow] 15:337-40.

355. TARASSEvich, L. M.

1950. On rearing of mulberry silkworms free from jaundice. Microbiology [Moseow] $19: 364-68$.

356. TARASSEVICH, L. M.

1953. In regard to obtaining mulberry silkworm (Bombyx mori) larvae free from yellow disease. Microbiology [Moscow] 22:311-15.

357. THALENHORST, $\mathrm{W}$.

1956. Biologischer Forstschutz: Therapie und Hygiene. Sammelreferat über die wichtigsten forstpathologischen Arbeiten der Jahre 1943-1954. V. Teil. Forstarchiv 27:217-26.

358. Thомpson, C. G.

1956 (1958). The use of certain entomogenous microorganisms to control the alfalfa caterpillar. Proc. 10th int. Congr. Ent., Montreal, 4:693.

359. Thompson, C. G., and E. A. Steinhaus

1950. Alfalfa caterpillar control (treatment of fields by airplane application of spray advances destruction of pest). Calif. Agric. 4(5):8, 16.

360. TiRELLI, M:

1931. Nota di tecnica sui granuli poliedrici. Annu. Staz. bacol. sper. Padova 46:43136.

361. TIRELli, M., and L. K. Wong

1931. Alterazioni istologiche nei testicoli delle larve di "Bombyx mori" malate di giallume. Annu. Staz. bacol. sper. Padova 46:401-408.

362. TOKYUASU, K.

1953. The structures and the development of silkworm polyhedra. Enzymologia $16: 62-68$.

363. TokUYasu, $\mathrm{K}$.

1956. Morphological study of inclusion body of silkworm jaundice. Kyushu J. med. Sci. 7:108-20.

364. TomLin, S. G., and J. Monro

1955. The structure of a polyhedral virus from the larvae of Ardices glatignyi Le Guil. (Lepidoptera:Arctiidae). Biochim. biophys. Acta 18:202-8.

365. TOTHILL, J. D.

1956 (1958). Some reflections on the causes of insect outbreaks. Proc. 10th int. Congr. Ent., Montreal, 4:525-31.

366. von Tubeur, C.

1892. Die Krankheiten der Nonne (Liparis monacha). Forstl.-naturw. Z. 1:34-47, $62-79$.

367. von TUBEUF, C.

1892. Weitere Beobachtungen über die Krankheiten der Nonne. Forstl.-naturw. Z. $1: 277-79$.

368. Umeya, Y., K. Aizawa, and K. Nakamura

1955. Injection experiments of the silkworm jaundice virus into the silkworm eggs 
369. VAGO, C.

with some consideration on the multiplication and induction of the virus (A preliminary note). Sanshi-kenkyu No. 13-2:5-12.

1950. Diversité des symptômes extérieurs dans une même maladie à ultravirus d'insectes. C.R. Acad. Sci. [Paris] 231:1587-88.

370. VAGo, C.

1951. Mise en évidence des polyèdres de la grasserie par coloration de leurs contours en vue de l'établissement du diagnostic de la maladie. Bull. Microscop.

37.1. VAGo, C. appl. [Paris] 1:99-100.

1951. Mise en évidence des polyèdres par colorations negatives dans le diagnostic des 372. VAGo, C. maladies à ultravirus d'insectes. Mikroskopie 6:228-31.

1951. Les possibilités de diagnostic de la polyédrie dans les cadavres de Bombyx 373. VAGo, C. mori L. en voie de décomposition. Mikroskopie 6:291-94.

1951. Phénomènes de "Latentia" dans une maladie à ultravirus des insectes. Rev. canad. Biol. 10:299-308.

374. VAGo, C.

1951. Polyédrie du Bombyx mori L. aux symptômes atypiques. Bull. Soc. ent. Fr.

375. VAGo, C. 56:108-11.

1952. Emploi du bleu Victoria pour la mise en évidence des polyèdres dans les 376. VAGo, C. maladies à ultravirus d'insectes. Bull. Microscop. appl. [Paris] 2:21-22.

1952. Maladies latentes et tolerance symbiotique chez les invertebrés. 6 me Congr. int. 377. VAgo, C. Path. comp., Madrid, 1:121-33.

1953. Essais d'élimination de la grasserie par activation de sa phase latente. Rev. 378. VAGo, C. Ver à Soie 5:73-81.

1953 (1955). Facteurs alimentaires et activation des viroses latentes chez les insectes. Act. 6me Congr. int. Microbiol., Rome, 5:556-64.

379. VAGo, C.

1953. Virose aiguë à polyèdres déclenchée par action du fluorure de sodium. Ex-

380. VAGo, C. perientia 9:466-68.

1954. Action du permanganate de potassium comme désinfectant des oeufs d'in381. Vago, C. sectes vis-à-vis des viroses. Bull. Soc. zool. Fr. 79:138-41.

1954. Différenciation des corps d'inclusion des viroses d'insectes au contraste de 382. VAGo, C. phase. Mikroskopie 9:364-66.

1954. Limites biologiques du traitment désinfectant sur oeufs d'insectes a l'hydroxyde de potassium contre les virus du groupe Borrelina. C.R. Soc. Biol.

383. VAGo, C. [Paris] 148:255-57.

1956. L'enchaînement des maladies chez les insectes. (Disease interaction in insects.)

384. VAGo, C. Rev. Ver à Soie 8:39-47.

1957. Multiplication du virus Borrelina bombycis sur chrysalides de vers à soie.

385. VAGo, C. C.R. Acad. Sci. [Paris] 245:2115-17.

1958. Virose intestinale chez la processionnaire du pin Thaumetopoea pityocampa Schiff. (Lepidoptera). Entomophaga 3:35-37.

386. Vago, C., and C. R. CAYroL

1955. Une virose à polyèdres de la noctuelle gamma Plusia gamma L. (Lepidoptera.) Ann. Epiphyt., Ser. C, 6:421-32. 
387. Vago, C., O. Croissant, and P. Lépine

1955. Démonstration au microscope électronique du développement intranucléaire du virus de la grasserie. Ann. Inst. Pasteur [Paris] 89:364-66.

388. VAGo, C., and P. HAUdURoY

1954. Resistance à la lyophilisation, du virus de la polyédrie de Thaumetopoea pityocampa Schiff. (Lepidoptera). Leeuwenhoek ned. Tijdschr. 20 : 141-44.

389. VAGo, C., and L. VASILJEVIĆ

1958. Polyedrie cytoplasmique chez l'ecaille fileuse (Hyphantria cunea Drury, Lep. Arctiidae). Entomophaga 3:197-98.

390. VASILJEVIĆ, L.

1957. Uticaj temperaturnih kolebanja u prirodi na razvoj poliedrije kod gubara. (Influence of the temperature oscillations in the nature upon the development of the polyhedry among gypsy moths.) Zasht. Bilja No. 41-42: 57-66.

391. VASILJEVIĆ, L.

1957. Udeo poliedrije i ostalih obolenja kod nastale gradacije gubara 1957 godine $\mathrm{u}$ NR Srbiji. (Share of the polyhedry and other diseases in the reduction of the gipsy moth gradation which took place in the PR of Serbia in 1957.) Zasht. Bilja No. 41-42:123-137.

392. VEBER, J.

1957. A eytoplasmic polyhedral disease of the gipsy moth (Lymantria dispar L.). Nature [Lond.] 179:1304-5.

393. VIDA, M. H.

1527. De bombyce. Translation by M. Bonafous. Le ver à soie, poëme en deux chants, de Marc-Jérome Vida, traduit en vers français, avec le texte latin en regard. Ed. 2. Bouchard-Huzard and Challamel, Paris, 1844. ix-152 pp.

394. WACHTL, F. A., and K. KoRNAUTH

1893. Beiträge zur Kenntniss der Morphologie, Biologie und Pathologie der Nonne (Psilura monacha L.) und Versuchsergebnisse über den Gebrauchswert einiger Mittel zur Vertilgung der Raupe. Mitt. forstl. Versuchsw. Öst. No. 16.

395. WAHL, B. $38 \mathrm{pp}$.

1910. Über die Polyederkrankheit der Nonne (Lymantria monacha L.). Zbl. ges. Forstw. 36:193-212.

396. WALKER, $P$.

1891. The grasserie of the silk-worm. Insect Life [Washington] 3:445-51.

397. WALLIS, R. C.

1957. Incidence of polyhedrosis of gypsy-moth larvae and the influence of relative humidity. J. econ. Ent. 50:580-83.

398. WatANABE, S.

1951. Studies on the grasserie virus of the silkworm, Bombyx mori. IV. Physical and chemical effects upon the virus. Jap. J. exp. Med. 21:299-313.

399. WEISER, J.

1949. Deux nouvelles infections à virus des insectes. Ann. Parasit. hum. comp. 24 : 259-64.

400. WEISER, J.

1958. Zur Taxonomie der Insektenviren. Čsl. Parasit. 5:203-11.

401. WEISER, J., and J. VEBER

1954. The possibilities of biological control of the fall webworm (Hyphantria cunea Drury). Folia zool. ent. 3:55-68.

402. WhLLINGTON, E. F.

1954. The amino acid composition of some insect viruses and their characteristic inclusion-body proteins. Biochem. J. $57: 334-38$.

403. White, G. F.

1929. Preliminary observations on the polyhedral diseases of insects. J. Parasit. $16: 107$.

404. Williams, R. C.

1954. Electron microscopy of viruses. Advanc. Virus Res. 2:183-239.

405. Williams, R. C., and K. M. SMITH

1957. A crystallizable insect virus. Nature [Lond.] 179:119-20. 
406. Williams, R. C., and K. M. Smith

1958. The polyhedral form of the Tipula iridescent virus. Biochim. biophys. Acta $28: 464-69$.

407. WitTig, G., and J. Franz

1957. Zur Histopathologie der Granulose von Choristoneura murinana (Hbn.) (Lepidopt., Tortricidae). Naturwissenschaften 44:564-65.

408. WyaTT, G. R.

1952. Specificity in the composition of nucleic acids. Exp. Cell Res. 2:201-17.

409. WYATT, G. R., and S. S. CoHEN

1953. The bases of the nucleic acids of some bacterial and animal viruses: the occurrence of 5-hydroxymethylcytosine. Biochem. J. 55:774-82.

410. WYATT, S. S.

1956. Culture in vitro of tissue from the silkworm, Bombyx mori L. J. gen. Physiol. $39: 841-52$.

411. W ҮскоғF, R. W. G.

1953 (1955). Electron microseopic evidence on virus proliferation. 6me Congr. int. Microbiol., Rome, 6th Symposium (Interaction of viruses and cells) : 54-57; Symposia, summaries: 178 .

412. WYNIGER, $R$.

1957. Beobachtungen über Raupenkrankheiten und Versuche zu deren Bekämpfung. Mitt. ent. Ges. Basel 7:61-76.

413. Xeros, N.

1953. Development of intranuclear inclusions in virus-diseased cells of lepidopterous larvae. Nature [Lond.] 172:309-10.

414. XEROS, N.

1953. Origin and fate of the virus bundles in nuclear polyhedroses. Nature [Lond.] $172: 548-49$.

415. Xeros, N.

1956. The virogenic stroma in nuclear and cytoplasmic polyhedroses. Nature [Lond.] 178:412-13.

416. YAMAFUJI, K.

1949. Ueber die experimentelle Produktion des Virus hauptsächlich nach Versuchen am Seidenwurm. Enzymologia 13:223-28.

417. YAMAFUJI, $\mathrm{K}$.

1950. Conversion of nitrites into oximes in silkworms and its relation to the experimental production of virus disease. Nature [Lond.] 165:651-52.

418. YamaFuJI, $\mathrm{K}$.

1952. Effect of nitrite on the nuclear structure in the silkworm. Nature [Lond.] $170: 126$.

419. YAMAFUJI, $\mathrm{K}$.

1952. Mechanism of artificial virus formation in silkworm tissues. Enzymologia $15: 223-31$.

420. YAMAFUJI, K.

1953. Metabolism abnormality and virus production. Rep. agric. Tech. Kyushu $10: 1-2$.

421. YAMAFUJI, K.

1955. Enzymology of virugenesis. Rep. agric. Biochem. Kyushu 15:1-6.

422. YAMAFUJI, K.

1955. Polyhedrosis virus and desoxyribonuclease controlling gene. Rep. agric. Biochem. Kyushu $15: 7-12$.

423. YamafuJi, $\mathrm{K}$.

1956. Presence of deoxyribonuclease in silkworm polyhedral virus. Nature [Lond.] $178: 89$.

424. YAMAFUJI, K.

1956 (1958). Role of deoxyribonucleic acid and deoxyribonuclease in induction processes of polyhedrosis virus. Proc. 10th int. Congr. Ent., Montreal, 4: 731-36.

425. YAMAFUJI, K., and T. AKITA

1952. On transoximation. Enzymologia 15:313-18. 
426. YamafuJI, K., T. AKITA, and M. INAOKA

1950. Experimental production of silkworm virus under sterile conditions. Enzymologia $14: 164-69$.

427. YamafuJi, K., T. AKITA, and I. Namba

1952. Relation between infectious ability of silkworm polyhedra and virus-producing substances. Enzymologia $15: 215-18$.

428. Yamafuji, K., T. AKita, and H. SaKamoto

1951. Virus activity of silkworm polyhedra. Enzymologia 15:126-29.

429. YaMAFUJI, K., and M. AOKI

1956. Influence of chemical treatment on amylase and sucrase in silkworm bodies. Enzymologia 17:300-304.

430. YAMAFUJI, K., and T. Cho

1947. Weitere Studien zur Entstehung des Seidenraupenpolyedervirus ohne Virusinfektion. Biochem. Z. 318:95-100.

431. YamafuJi, K., M. Eto, M. Aoki, and J. Mukai

1956. Function of the nucleus of silkworm virus in the eclipse period. Enzymologia $17: 249-55$.

432. YamafuJi, K., M. Eto, and F. Yoshihara

1954. Effect of nuclear preparations from infected silkworms on the development of polyhedrosis. Enzymologia $17: 164-68$.

433. YamafuJI, K., S. FuJiI, and T. Akita

1950. Ueber die chemischen Prozesse bei der künstlichen Virus-Erzeugung im lebendigen Körper. Enzymologia 14:24-29.

434. YamafuJi, K., K. Hayashi, and M. Shimamura

1954. Ultracentrifugal investigation of silkworm polyhedra. Enzymologia 17:15556.

435. YamafuJi, K., and K. Hirayama

1955. Contact method for inducing polyhedral disease. Enzymologia 17:229-36.

436. YamafuJI, K., and K. Hirayama

1957. Nucleases and proteases in silkworms in the early stage of viral infection and chemical induction. Enzymologia 18:120-24.

437. YamafuJi, K., K. Hirayama, and A. Miyata

1956. Depolimerization of desoxyribonucleic acid by virus inducer and silkworm enzyme. Enzymologia $17: 352-58$.

438. YamafuJi, K., K. Hirayama, and M. Sato

1957. Desoxyribonuclease in silkworms treated with virosis inductors. Enzymologia $18: 22-27$.

439. Yamafuji, K., I. Igaue, and M. Sato

1952. Effect of chemicals upon the solubility of the polyhedrosis virus of silkworms. Enzymologia 15:219-22.

440. YamafuJi, K., T. KaWaKami, and K. Shinohara

1952. On an enzyme in silkworm which eatalyzes the transformation of oximes into amino compounds. Enzymologia 15:199-203.

441. YamafuJi, K., and Y. Kosa

1944. Zum Chemismus der Virus-Entstehung. Biochem. Z. 317:81-86.

442. YAMAFUJI, K., Y. MatSUKURA, and M. ETo

1953. Electrophoresis of silkworm polyhedra. Enzymologia 15:327-28.

443. YamaFuJi, K., J. MUKaI, and F. Yoshihara

1957. Polyhedral virus induction by desoxyribonuclease and trypsin. Enzymologia $18: 28-32$.

444. Yamaf'UJI, K., and H. OMURA

1950. The formation of silkworm virus by acetoxime feeding. Enzymologia 14: $120-23$.

445. YAMAFUJI, K., and H. OMURA

1952. On the oximase. Enzymologia $15: 296-302$.

446. YAMAFUJI, K., and H. OMURA

1954. A study of polyhedral virus formation with radioactive phosphorus. Enzymologia $17: 28-30$. 
447. Yamafuji, K., H. OMura, and M. MiURA

1953. On the transoximase. Enzymologia 16:75-80.

448. YamaFuJi, K., H. OMURA, and N. Отомо

1958. An immunological investigation of viral polyhedrosis. Enzymologia 19:17579.

449. YamafuJi, K., H. OMURA, and T. Sakamoto

1952. Variation of the activity of some enzymes in silkworm by chemical feeding. Enzymologia $15: 210-14$.

450. YAMAFUJi, K., H. OMURA, and M. Sato

1953. Polyhedron production in offspring of virus-infected silkworms. Enzymologia $15: 362-65$.

451. Yamafuji, K., H. Omura, and M. Sato

1954. Injection method for inducing polyhedrosis in silkworm. Enzymologia 16: $329-35$.

452. YamafuJi, K., H. OMURA, and K. Watanabe

1958. Distribution and transmission of radioactive phosphorus during development of viral polyhedrosis. Enzymologia $19: 157-62$.

453. YamafuJi, K., H. Sakamoto, and T. AKita

1952. Influence of chemical treatment on descendants in silkworm. Enzymologia $15: 207-9$.

454. YAMAFUJI, K., M. SATo, and J. KishiKawA

1958. Chemical virogenesis and remote infection in silkworm. Enżymologia 19:15156.

455. YamafuJi, K., M. SATo, and I. Nagata

1958. Chemical virogenesis and virogenic treatment in silkworm. Enzymologia 19: 48-52.

456. YamaFuJi, K., M. Shimamura, and F. Yoshihara

1954. Behaviour of nucleic acids in formation processes of silkworm virus. Enzymologia $16: 337-42$.

457. YAMAFUJI, K., and Y. SHIROZU

1944. Die Abhängigkeit der Neubildung des Virusproteins von der Erniedrigung der Katalase. Biochem. Z. 317:94-98.

458. YamaFuJi, K., K. So, and K. Soo

1941. Die Wirkung des Seidenraupenpolyedervirus auf die Atmung und Katalase der Hefe. Biochem. Z. 311:203-8.

459. YamafuJi, K., K. WAdA, and M. SATO

1951. Solubility of polyhedral bodies of silkworm. Enzymologia 15:130-33.

460. YAMAFUJI, K., and F. YoshiHara

1950. On the virus production and oxime formation in silkworms fed with nitrites. Enzymologia 14:124-27.

461. YamaFuJi, K., and F. YoshiHara

1953. Embryonic development and virus formation in silkworm. Enzymologia 15: 321-26.

462. YamafuJi, K., and F. Yoshihara

1953. Virus formation in interspecific hybrids of silkworms. Enzymologia 15:36670.

463. Yamafuji, K., F. Yoshihara, and M. Eto

1952. Morphological changes of adipose cells in silkworms after administering nitrite or hydroxylamine. Enzymologia 15:204-6.

464. YamafuJi, K., F. Yoshihara, M. Eto, and H. Omura

1955. Induction of polyhedrosis by injecting desoxyribonucleic acid fractions isolated from healthy silkworms. Enzymologia $17: 237-44$.

465. YamafuJi, K., F. Yoshihara, J. Mukai, and M. Sato

1957. Virugenic action of silkworm desoxyribonucleate. Enzymologia 18:125-30.

466. YamafuJi, K., F. YoshiHara, and M. Sato

1954. Eclipse period of polyhedral disease. Enzymologia 17:152-54.

467. YamafuJi, K., F. Yoshihara, and M. Shimamura

1956. Action of ribonuclease in relation to the formation of silkworm virus. Enzymologia $17: 286-90$. 
468. Yamafuji, K., F. Yoshihara, and H. Wada

1950. Formation of oxime in silkworms after feeding with inorganic nitrogenous salts. Enzymologia $14: 170-76$.

469. YamafuJi, K., F. Yoshihara, and S. Yoshimoto

1953. Induction of polyhedrosis in progenies of chemically treated silkworms. Enzymologia $16: 51-55$.

470. YAMAFUJI, K., and T. YUKI

1947. Über die Vorbeugung gegen eine Viruskrankheit durch Fütterung mit Katalase beim Seidenspinner. Biochem. Z. 318:107-11.

471. YAMAFUJI, K., and T. YUKI

1950. Über den Mechanismus der Virusentstehung in der Zelle. J. Fac. Agric. Kyushu Univ. 9:317-23.

472. Yoshinara, F.

1956. Decomposition of pepton in polyhedra-diseased silkworms. Sci. Bull. Fac. Agric. Kyushu 15:473-77.

473. Yoshinara, F.

1956. Peptidase in virus-diseased silkworms. Sci. Bull. Fac. Agric. Kyushu 15: 479-81. 


\section{INDEX TO GENERIC AND SPECIFIC NAMES OF HOST INSECTS}

(Subgeneric names are in parentheses)

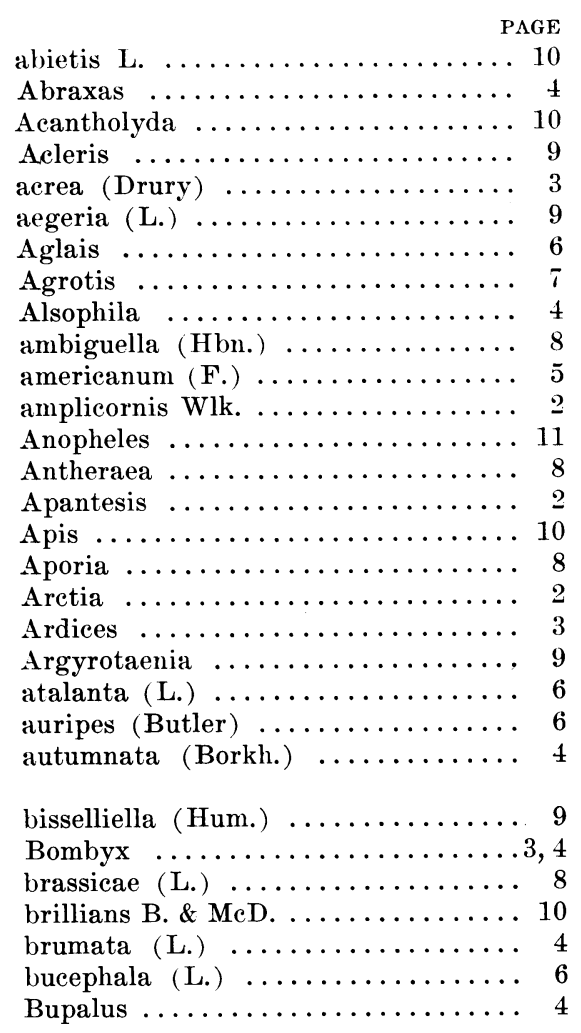

caberata Guen. ............ 5

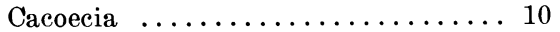

caja (L.) $\ldots \ldots \ldots \ldots \ldots \ldots \ldots \ldots \ldots 2$

californica Pack. ............ 4

californicum (Pack.) ......... 5

cardui (L.) .............. 6

cautella (Wlk.) ............ 8

Celerio .................... 9

Cephalcia ................ 10

(Cephalcia) ............... 10

Cerura .................. 6

Chironomus .................. 11

Choristoneura ............ 10

chrysorrhoea (L.) .......... 5

cinnabarinus (Bdv.) .......... 2

clandestina (Harr.) .......... 8

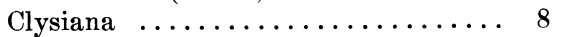

coenia Hbn. .............. 6

Colias ................. 8

constrictum $($ Stretch $) \ldots \ldots \ldots \ldots \ldots$

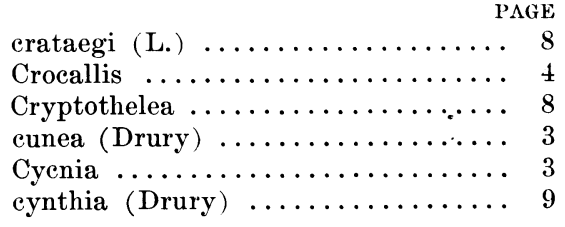

Dasychira .............. 5

defoliaria (L.) $\ldots \ldots \ldots \ldots \ldots \ldots \ldots \ldots 4$

Dendrolimus ............. 5

Diacrisia ................. 3

Diataraxia .............. 7

Diprion ............... 10

Dira ..................... 9

dispar (L.) $\ldots \ldots \ldots \ldots \ldots \ldots \ldots \ldots$

disstria Hbn............... 5

dominula (L.) $\ldots \ldots \ldots \ldots \ldots \ldots \ldots$

Drepana .............. 4

Drosophila $\ldots \ldots \ldots \ldots \ldots \ldots \ldots 1$

elinguaria (L.) $\ldots \ldots \ldots \ldots \ldots \ldots \ldots$

Ennomos ............... 4

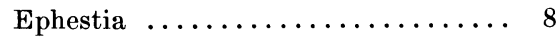

Estigmene .............. 3

Eucosma $\ldots \ldots \ldots \ldots \ldots \ldots \ldots \ldots$

Eulype $\ldots \ldots \ldots \ldots \ldots \ldots \ldots \ldots$

euphorbiae (L.) $\ldots \ldots \ldots \ldots \ldots \ldots \ldots 9$

Euplagia ................ 3

Euproctis $\ldots \ldots \ldots \ldots \ldots \ldots \ldots \ldots$

Euxoa .............. 7

fimbriata (von Schreber) ....... 7

fiscellaria fiscellaria (Guen.) ...... 4

fiscellaria lugubrosa (Hulst) ...... 4

flammea Schiff. ............

flava (Bremer) ............ 5

fragile $($ Stretch $) \ldots \ldots \ldots \ldots \ldots \ldots$

fuliginosa (L.) ............ 3

fumiferana (Clem.) .......... 10

Galleria ................ 4

gamma (L.) ............ 7

(Gilpinia) $\ldots \ldots \ldots \ldots \ldots \ldots \ldots \ldots$

glatignyi (Le Guill.) .......... 3

griseana (Hbn.) ........... 7

grossulariata (L.) $\ldots \ldots \ldots \ldots \ldots \ldots 4$

Harrisina .................. 10

hastata (L.) ............. 4

Heliothis ............... 7

Hemerocampa ...........5, 6

Hemileuca .............. 8 


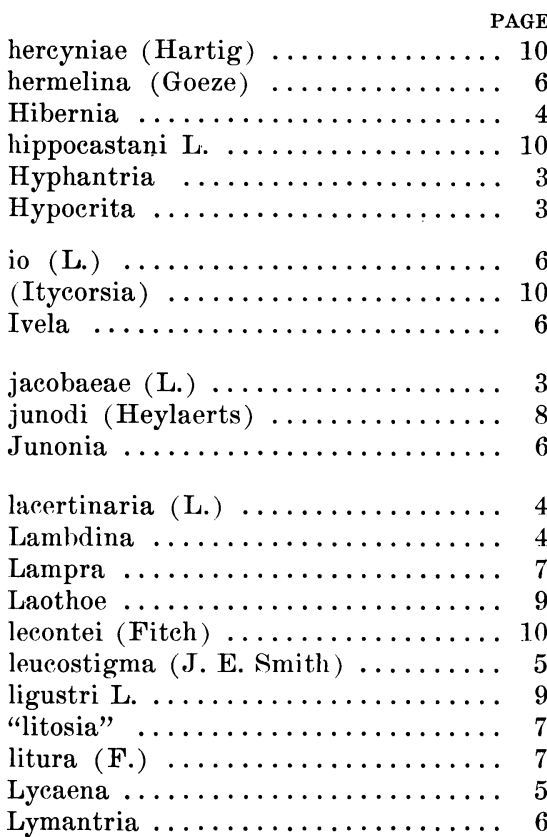

machaon L. .............. 7

maia (Drury) ............ 8

Malacosoma ............. 5

mandarina Moore ............ 4

margaritosa (Haw.) $\ldots \ldots \ldots \ldots \ldots \ldots 7$

mauritia (Bdv.) ........... 8

megera (L.) .............. 9

Melanchra .............. 7

melanogaster Meig. . . . . . . . . . 11

mellifera L. ............... 10

mellonella (L.) ............ 4

Melolontha .............. 10

melolontha L. ............. 10

mendica (Clerck) .......... 3

meticulosa (L.) ............ 7

milleri Busck ............. 4

monacha (L.) $\ldots \ldots \ldots \ldots \ldots \ldots \ldots 6$

mori (L.) $\ldots \ldots \ldots \ldots \ldots \ldots \ldots \ldots, 4$

murinana (Hbn.) $\ldots \ldots \ldots \ldots \ldots \ldots$

napi (L.) $\ldots \ldots \ldots \ldots \ldots \ldots \ldots \ldots$

nararia (Moore) ........... 5

Natada ................ 5

Nematus ................. 11

nemoralis C. G. Thomson ....... 10

Neodiprion .............. 10

neustria (L.) $\ldots \ldots \ldots \ldots \ldots \ldots \ldots \ldots$

ni (Hbn.) .............. 8

Nymphalis $\ldots \ldots \ldots \ldots \ldots \ldots$

ocellata atlanticus Austaut ....... 9 ochrogaster (Guen.) .......... 7

oleracea (L.) $\ldots \ldots \ldots \ldots \ldots \ldots \ldots \ldots 7$

olfaciens Benson ............ 11

Operophtera ............. 4

Oporinia .............. 4

Ourapteryx $\ldots \ldots \ldots \ldots \ldots \ldots$

paludosa Meig. ............. 11

Panaxia .................. 3

Panolis ................ 7

paphia mylitta (Drury) ........ 8

Papilio .............. 7

Pararge ................ 9

pellionella (L.) ............ 9

Peridroma .............. 7

pernyi Guér.-Men. ........... 8

persicariae (L.) .......... 7

Phalera ............... 6

philodice eurytheme Bdv. ....... 8

philodice philodice Latr. . . . . . . . . 8

phlaeas (L.) $\ldots \ldots \ldots \ldots \ldots \ldots \ldots \ldots 5$

Phlogophora ............ 7

Phragmatobia ............ 3

Phryganidia .............. 4

Pieris $\ldots \ldots \ldots \ldots \ldots \ldots \ldots \ldots$

pini L. ............... 5

piniarius (L.) $\ldots \ldots \ldots \ldots \ldots \ldots \ldots 4$

pityocampa Schiff. ........... 9

Plusia ............... 7

pluviale (Dyar) ............ 5

polyphemus (Cram.) .......... 8

pometaria (Harr.) .......... 4

populi (L.) $\ldots \ldots \ldots \ldots \ldots \ldots \ldots \ldots, 9$

Porthetria .............. 6

praefica Grote ............. 7

pratti banksianae Roh. .......... 10

pratti pratti (Dyar) ......... 10

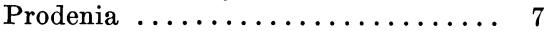

pronuba (L.) $\ldots \ldots \ldots \ldots \ldots \ldots \ldots \ldots . \ldots$

Pseudaletia ............... 7

pseudoconspersa (Strand) ...... 5

pseudotsugata McD. .......... 6

Pterolocera ............... 2

pudibunda (L.) $\ldots \ldots \ldots \ldots \ldots \ldots \ldots \ldots, 5$

purpurata (L.) ........... 3

pyri (Schiff.) $\ldots \ldots \ldots \ldots \ldots \ldots \ldots$

quadripunctaria (Poda) ........ 3

quercinaria (Hfn.) .......... 4

rapae (L.) $\ldots \ldots \ldots \ldots \ldots \ldots \ldots \ldots \ldots 8$

Recurvaria ............. 4

ricini (Bdv.) $\ldots \ldots \ldots \ldots \ldots \ldots \ldots \ldots 9$

Sabulodes $\ldots \ldots \ldots \ldots \ldots \ldots \ldots$

salicis (L.) $\ldots \ldots \ldots \ldots \ldots \ldots \ldots \ldots 6$

sambucaria (L.) $\ldots \ldots \ldots \ldots \ldots \ldots 5$ 
PAGE

PAGE

Samia $\ldots \ldots \ldots \ldots \ldots \ldots \ldots \ldots \ldots$

Tipula ................ 11

Saturnia $\ldots \ldots \ldots \ldots \ldots \ldots \ldots \ldots$

segetum (Schiff.) ........... 7

sertifer (Geoff.) ............ 10

Smerinthus ............. 9

Spaelotis .............. 8

Sphinx ............... 9

Spodoptera ............. 8

Stilpnotia ............... 6

subpictus Grassi .......... 11

tentans F. .............. 11

Tetranychus ............... 2

Thaumetopoea ............ 9

Theophila ............... 4

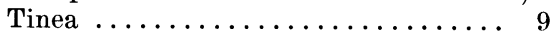

Tineola ................ 9

(Tipula) ................ 11

Trichoplusia ............. 8

Triphaena ............. 8

unipuncta (Haw.) .......... 7

urticae (L.) $\ldots \ldots \ldots \ldots \ldots \ldots \ldots \ldots 6$

Vanessa ................. 6

variana (Fern.) ............ 9

velutinana $($ Wlk. $\ldots \ldots \ldots \ldots \ldots \ldots$

villica (L.) $\ldots \ldots \ldots \ldots \ldots \ldots \ldots \ldots \ldots$

vinula (L.) .............. 6

virescens (F.) $\ldots \ldots \ldots \ldots \ldots \ldots \ldots \ldots$

virgo (L.) $\ldots \ldots \ldots \ldots \ldots \ldots \ldots \ldots \ldots$

zea (Boddie) $\ldots \ldots \ldots \ldots \ldots \ldots \ldots$ 
The journal Hilgardia is published at irregular intervals, in volumes of about 600 pages. The number of issues per volume varies.

Subscriptions are not sold. The periodical is sent as published only to libraries, or to institutions in foreign countries having publications to offer in exchange.

You may obtain a single copy of any issue free, as long as the supply lasts; please request by volume and issue number from:
Agricultural Publications
207 University Hall
2200 University Avenue
Berkeley 4, California

The limit to nonresidents of California is 10 separate issues on a single order. A list of the issues still available will be sent on request. 